LUCAS REIS VERDEROSI

\title{
INTERVENÇÃO MUNICIPAL NO DOMÍNIO ECONÔMICO: COMPETÊNCIA E LIMITES NA INTERPRETAÇÃO DO INTERESSE PÚBLICO LOCAL
}

Dissertação de Mestrado

Orientadora: Prof. ${ }^{a}$ Associada Dra. Monica Herman Salem Caggiano

São Paulo 
INTERVENÇÃO MUNICIPAL NO DOMÍNIO ECONÔMICO

COMPETÊNCIA E LIMITES NA INTERPRETAÇÃO DO INTERESSE PÚBLICO LOCAL

Dissertação apresentada a Banca Examinadora do Programa de Pós-Graduação em Direito, da Faculdade de Direito da Universidade de São Paulo, como exigência parcial para obtenção do título de Mestre em Direito, na área de concentração Direito Constitucional, sob a orientação da Prof. a Associada Dra. Monica Herman Salem Caggiano.

Universidade de São Paulo

Faculdade de Direito

São Paulo 


\section{Catalogação da Publicação}

\section{Serviço de Biblioteca e Documentação}

\section{Faculdade de Direito da Universidade de São Paulo}

Verderosi, Lucas Reis Intervenção Municipal no Domínio Econômico:

Competência e Limites na Interpretação do Interesse Público Local ;

Lucas Reis Verderosi ; orientadora Monica Herman Salem Caggiano -- São Paulo, 2020.

248

Dissertação (Mestrado - Programa de Pós-Graduação em Direito do Estado) - Faculdade de Direito, Universidade de São Paulo, 2020.

1. Município. 2. Domínio Econômico. 3. Competência. 4. Intervenção. 5. Interesse Local. I. Caggiano, Monica Herman Salem, orient. II. Título. 


\section{LISTA DE ABREVIATURAS}

ADCT - Ato das Disposições Constitucionais Transitórias

ADI - Ação Direta de Inconstitucionalidade

ADPF - Arguição de Descumprimento de Preceito Fundamental

AI - Ato Institucional

CF - Constituição Federal

CPI - Comissão Parlamentar de Inquérito

CRFB - Constituição da República Federativa do Brasil

EC - Emenda Constitucional

IBAM - Instituto Brasileiro de Administração Municipal

IPTU - Imposto Predial e Territorial Urbano

IPVA - Imposto sobre Propriedade de Veículos Automotores

ISS - Imposto sobre Serviços

ISSQN - Imposto sobre Serviços de Qualquer Natureza

ONU - Organização das Nações Unidas

STF - Supremo Tribunal Federal

STJ - Superior Tribunal de Justiça

RE - Recurso Extraordinário

REsp - Recurso Especial 


\section{Agradecimentos}

A Deus, por justo.

Aos meus Pais, por certo.

Aos meus Avós, por tudo.

Às minhas Irmãs, por óbvio.

À Professora Monica Herman Salem Caggiano, devo agradecer pela inspiração fácil e pela orientação precisa. Admirá-la é escolher entre os muitos porquês.

À Professora Elza Antonia Pereira Cunha Boiteux, por ter-me apontado uma porta que, depois de aberta, lançou-me no precipício certo. Suas orientações e indicações bibliográficas fizeram do meu trabalho um verdadeiro despertar.

Ao Professor Cláudio Salvador Lembo, cujo humor e sagacidade ensinam mais que mil tratados. 
Para a Gabi, sempre. 
"É tempo de se aprimorarem as instituições nesta América e o melhor prenúncio desta caminhada é saber que se começa pelo município, fonte primária de cidadania e de práticas cidadãs.”

(Cláudio Lembo, 2007) 


\section{RESUMO}

VERDEROSI, Lucas Reis. INTERVENÇÃO MUNICIPAL NO DOMÍNIO ECONÔMICO: Competência e Limites na Interpretação do Interesse Público Local. 248 p. Dissertação de Mestrado - Faculdade de Direito, Universidade de São Paulo, São Paulo, 2020.

Esta dissertação de mestrado pretende analisar as bases constitucionais da intervenção municipal no domínio econômico. Dedicamos particular atenção aos estudos da repartição de competências em nosso federalismo e das formas de intervenção do Estado na economia. Foram verificados, inicialmente, os limites da interpretação do interesse público, momento em que apresentamos os debates doutrinários a esse respeito. Após, dedicamo-nos em traçar o perfil interpretativo da regra insculpida no art. 30, I, da Constituição Federal, que confere aos Municípios a competência para legislar sobre assuntos de interesse local. Para os fins desse estudo, também foram consideradas as muitas formas pelas quais as municipalidades interagem com os agentes econômicos, a partir, sempre, de um ponto de vista constitucional, de modo a conferir, o quanto possível, concretude ao propósito de delimitar as intersecções entre as competências que dizem respeito à intervenção do Estado na economia e aquelas constitucionalmente atribuídas ao Município.

Palavras-chave: Município. Domínio Econômico. Competência. Intervenção. Interesse Local 


\begin{abstract}
This dissertation seeks to analyze the constitutional bases of municipal intervention in the economic domain. We gave particular attention to the studies of the division of competences in our federalism and the forms of state intervention in the economy. Initially, the limits of the interpretation of the public interest were verified, at which point we presented the doctrinal debates in this regard. Afterwards, we dedicate ourselves in tracing the interpretative profile of the rule inscribed in art. 30, I, of Brazilian Constitution, which gives municipalities the competence to legislate on matters of local interest. For the purposes of this study, we also considered the many ways in which municipalities interact with economic agents, always from a constitutional point of view, so as to give as much concreteness as possible to delimit intersections between the competences that concern both, the State intervention in the economy and those constitutionally attributed to the municipality.
\end{abstract}

Keywords: Municipality. Economic Domain. Competence. Intervention. Local Interest. 


\section{SUMÁRIO}

INTRODUÇÃO.

\section{CAPÍTULO I - A POSIÇÃO DO MUNICÍPIO NA FEDERAÇÃO BRASILEIRA} E SUAS COMPETÊNCIAS CONSTITUCIONAIS.

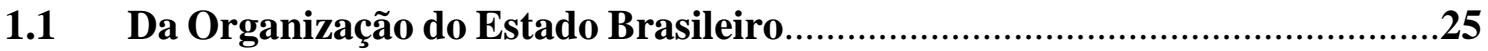

1.2 A Posição do Município no Estado Brasileiro....................................................38

1.3 Segurança Jurídica e Definição de Competências.......................................44

1.4 Classificação das Competências no Federalismo Brasileiro.........................47

1.4.1 Competência Administrativa..............................................................49

1.4.1.1 Competência administrativa exclusiva ou privativa...............................49

1.4.1.2 Competência administrativa residual.................................................51

1.4.1.3 Competência administrativa comum..................................................51

1.4.2 Competência Legislativa..........................................................................52

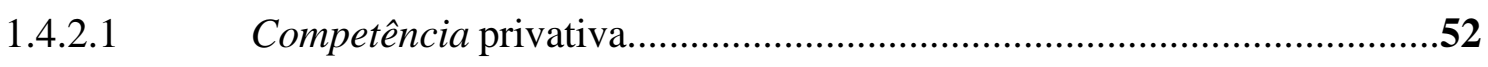

1.4.2.2 Competência residual ou delegada......................................................53

1.4.2.3 Competência concorrente e suplementar...............................................53

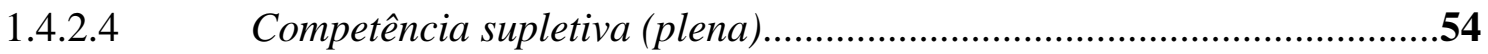

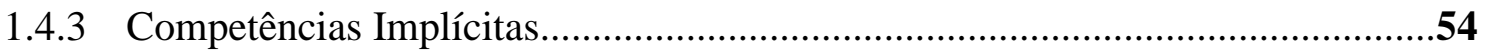


1.4.1.4 Competência administrativa em matéria municipal.........57

1.4.1.4.a) Competências administrativas explícitas próprias...................58

1.4.1.4.b) Competências administrativas explícitas comuns....................59

1.4.1.4.c) Competências administrativas implícitas................................61

1.4.2.5 Competência legislativa municipal..........................................61

1.4.2.5.a) Competências legislativas enumeradas................................62

1.4.2.5.b) Competências legislativas suplementares............................63

1.4.2.5.c) Competências legislativas supletivas........................................................66

CAPÍTULO II - CONCEITO JURÍDICO DE INTERESSE PÚBLICO LOCAL...73

2.1 Origem e Conceito de Interesse Geral...........................................................

2.2 Conceito Jurídico de Interesse Público...............................................................81

2.3 Interpretação do Interesse (Público) Local: Conflitos e Critérios de Decisão Preponderância de Interesses, Subsidiariedade e Proporcionalidade.....................109

CAPÍTULO III - INTERVENÇÃO DO MUNICÍPIO NA ATIVIDADE

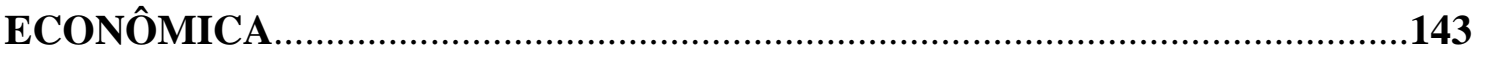

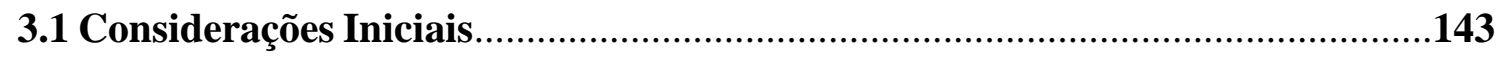

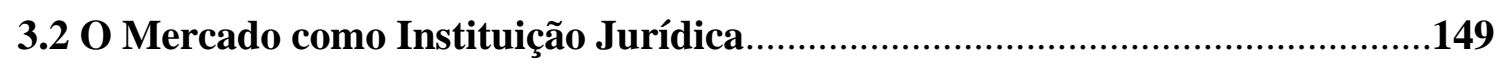

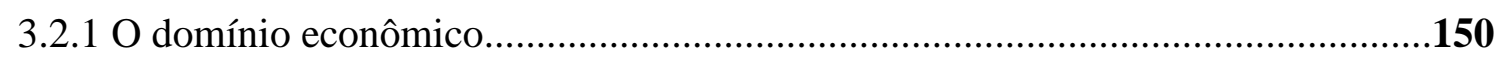

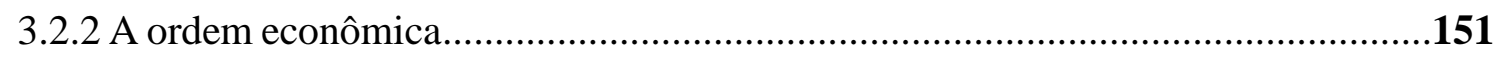

3.3 A Atuação do Estado no Domínio Econômico.................................................152

3.4 A Atuação do Município no Domínio Econômico e seus pressupostos................154

3.4.1 A atuação direta do Município no domínio econômico.........................................162

3.4.2 A atuação indireta do Município no domínio econômico......................................167 


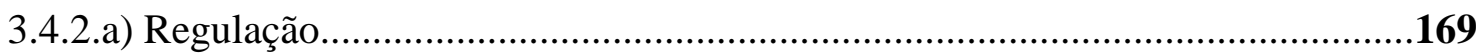

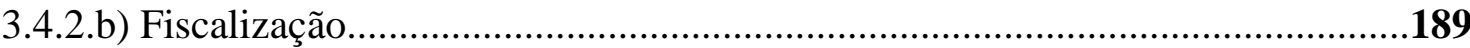

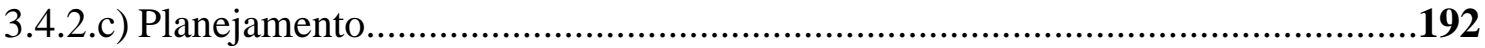

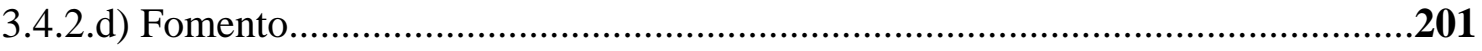

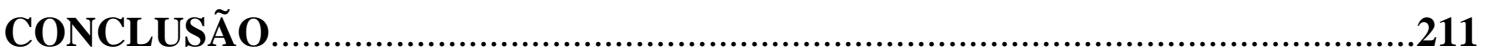

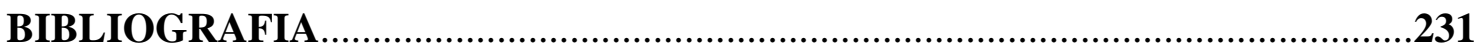




\section{INTRODUÇÃO}

Vive-se, na atualidade, a quarta revolução industrial, baseada na internet das coisas (Internet of Things) e na inteligência artificial (Artificial Intelligence). A supressão de intermediários, associada à criação de novos mercados, à extinção de mercados antigos e à dinamização dos fluxos, resulta em grande impacto na circulação e produção de bens e serviços.

O desenvolvimento tecnológico tem propiciado inéditos mecanismos de comunicação, formas de entretenimento, meios de locomoção, maneiras de se hospedar, financiar e monetizar ${ }^{1}$. O disruptivo prefere pedir desculpas a pedir licença, motivo pelo qual muitas dessas novidades, principalmente no setor de serviços, escapam ao tratamento jurídico por não se amoldarem perfeitamente às estruturas e institutos normativos tradicionais.

Isto se faz notar de maneira especialmente sensível nas cidades, onde há, nesse contexto: (i) intensificação e qualificação do uso da infraestrutura urbana ${ }^{2}$; e (ii) transmutação dos bens de consumo em bens de produção ${ }^{3}$.

Inovadoras formas de compartilhamento dos bens, por meio de plataformas que diminuem a assimetria de informações ao facilitar e publicizar avaliações do serviço com foco na fiscalização pelo próprio consumidor, geram um interessante modo de consumir.

A consequente otimização da economia impõe ao direito se conformar e cumprir sua função instrumental, deixando de ser empecilho para inovações disruptivas que, na essência, demonstram serem vantajosas para os consumidores. Ao mesmo tempo, a regulação estatal é imprescindível para acomodar os interesses em um ambiente de escassez

\footnotetext{
${ }^{1}$ A título ilustrativo, podemos citar entre as originais formas de consumo e comportamento: a comunicação pelo Whatsapp, o acesso ao entretenimento por meio do Netflix, a locomoção via Uber, a hospedagem pelo Airbnb, o financiamento graças ao crowdfunding e a monetarização devido ao uso de bitcoins.

${ }^{2}$ Como são exemplos as bicicletas e patinetes de aluguel, espalhadas pelas ruas e calçadas, ou os serviços de entrega, que intensificam sobremaneira o uso do viário.

${ }^{3}$ Como são exemplos os carros e casas que, de bens de consumo, subvertem-se em bens de produção, através de aplicativos como Uber ou Airbnb.
} 
e compartilhamento de bens/infraestrutura, revelado de modo tão mais nítido no meio urbano.

Desde a primeira revolução industrial, o avanço econômico de uma sociedade implica em um processo de urbanização que, se planejado, poderá impactar na forma como o processo de produção de riquezas propaga-se no tempo, com o fito de influenciar a maneira como a sociedade urbanizada produzirá bens e riquezas e apropriar-se-á do excedente gerado.

Consequentemente, o meio urbano, que é mais impactado por esta nova economia, requer um ator que, ao mesmo tempo, seja capaz de (i) intervir microscopicamente; e (ii) atentar para os impactos eminentemente locais da nova economia.

Ao Município brasileiro, enquanto ente federal vocacionado a atender às demandas particularmente locais, cabe essa função.

O Municipalismo parece ser uma dessas raras doutrinas jurídico-políticas de jaez genuinamente nacional ${ }^{4}$. Não há, seguramente, em outra parte do mundo, tratamento idêntico ao visto no Brasil, onde subsiste uma estrutura municipal que miniaturiza e reflete político-administrativamente o Estado Nacional (falecendo-lhe apenas um Poder Judiciário Municipal, outrora exercido, no Brasil Colônia, pelas Câmaras Municipais, função esta suprimida pela Lei $\mathrm{n}^{\circ} 1$ de outubro de $1828^{5}$ ).

Podemos afirmar que sopram, em nossos dias, renovados ventos Municipalistas 6.

\footnotetext{
${ }^{4} \mathrm{O}$ Municipalismo brasileiro tem várias faces, como ensina Antônio Carlos Otoni SOARES: “O municipalismo histórico-popular enfoca questões práticas e objetivas, tais como: posturas municipais [..] fomento econômico municipal e, modernamente, orienta-se no sentido de um cooperativismo de bases comunitárias [...] A corrente erudita do municipalismo brasileiro [...] elaborado pelas elites dirigentes urbanas, surge após a Independência do Brasil. É centralizadora por excelência [...] Municipalismo técnico-científico [...] pretende introduzir na estrutura municipal, princípios e métodos das ciências sociais e da ciência da administração, enfatizando as vantagens do planejamento e da eficiência administrativa." (grifo nosso). SOARES, Antonio Carlos Otoni. A Instituição Municipal no Brasil. São Paulo: Ed. Revista dos Tribunais, 1986.

${ }^{5}$ Conforme leciona Antônio Carlos Otoni SOARES: “A Justiça rústica das Câmaras Municipais foi avocada pelos 'coronéis' e mais tarde pelos delegados de polícia. Isto porque, nenhum bacharel em direito trocava a vida ociosa e segura das capitais, para se internar em algum município de Mato Grosso ou Goiás a fim de julgar "injúrias verbais" e pequenos furtos." Ibidem, p. 6.

${ }^{6}$ A doutrina antimunicipalista pode ser resumida pela seguinte citação de PONTES DE MIRANDA: “ $O$ município de hoje existe porque a lei quer. (Grifo do autor). Só a retórica dos juristas repetidores de velhos comentadores anglossaxões pode pretender que o município seja realidade viva. Os Estados Unidos da América e a República Argentina dotaram, nas suas Constituições, atitudes prudentes. O Brasil de 1891, na sua impetuosa idealidade desgarrada dos fatos, quis, de um jacto, criar a 'unidade política' que o estadualismo combaterá. Por isso, é de particular interesse verificar-se como procederam, a partir de vinte oito anos depois,
} 
A Proposta de Emenda Constitucional n ${ }^{\circ} 188 / 2019^{7}$, que prevê, entre outras medidas, transferência de parte dos recursos titularizados pela União, como resultado da exploração de petróleo, aos Estados e Municípios, é alardeada pelo governo de turno como um novo pacto federativo, tendente a uma maior descentralização do orçamento público.

Tal política exemplifica uma tendência de fortalecimento das comunidades, em linha com a recentíssima obra "The Third Pillar, how markets and the state leave the community behind" (2019), do Professor de Economia da Universidade de Chicago, Raghuran RAJAN.

Nesta obra, o renomado economista defende, em suma, que, com o tempo, Mercado e Estado afastaram-se das comunidades locais, o que agora vem sendo agravado pelas novas tecnologias disruptivas (RAJAN, 2019, p. 12).

Segundo o professor indiano (2019, p. 21): “Localism - in the sense of centering more powers, spending and activities in the Community - will be one way we will manage the centrifugal disorienting tendencies of global markets and new Technologies".

Em nome desse propósito, sugere o economista uma diminuição de poderes do governo federal em benefício do fortalecimento dos governos locais, de modo a tornar as trocas econômicas mais vibrantes e impedir uma "coalização profana entre gigantes econômicos e o Leviatã". ${ }^{8}$

os Estados europeus (sic) em que haveria razão para as autonomias municipais de velho estilo, reminiscências das cidades-Estados, restolhos de tempo que se foi' (1937:581.)" PONTES DE MIRANDA apud OTONI, Ibidem, p. 29. Tal posição, em nosso ver, ignora a cristalização consuetudinária do município na cultura política brasileira.

${ }^{7}$ Parte do chamado "Programa Mais Brasil", apresentado em novembro de 2019 pelo governo federal. Ressalvamos, todavia, a proposta dissonante de extinção de municípios com menos de 5 (cinco) mil habitantes e arrecadação própria inferior a $10 \%$ da receita total e absorção por municípios vizinhos. Trata-se de equivocada adoção da lógica centrípeta, por razões de natureza fiscal. Ainda sobre essa percepção negativa sobre o número de municípios no Brasil, Marta ARRETCHE alerta que: "tornou-se comum afirmar que o Brasil tem um número excessivo de municípios, o que impactaria negativamente o gasto público e a gestão nacional de políticas. O número de municípios no Brasil é em parte função de suas dimensões governamentais. A Suiça, com seus 7 milhões de habitantes, tem 3.000 governos locais, 4,3 para cada 10.000 habitantes. Os EUA, com 270 milhões de habitantes, têm 70.500 governos locais, 2,6 para cada dez mil habitantes. Na comparação internação das federações, o Brasil está no extremo mais baixo da escala, com 0,3 governos para cada dez mil habitantes (World Bank, 1999)". A centralização no Estado Federativo Brasileiro. Tese de Livre Docência. Faculdade de Filosofia, Letras e Ciências Humanas. Universidade de São Paulo, 2007. p. 62. A mera imposição constitucional de gratuidade na vereança atenderia à ideia de economicidade pretendida na extinção das estruturas de poder local.

${ }^{8}$ Segue o autor: "In this chapter, I have argued for a devolvement in powers from federal government through the regional government to the community. This will be an important step in rebalancing. Much as many small - and medium-sized companies help to distribute economic power and keep the unholy coalition of be hemot hand leviathan from forming, the empowerment of many small communities helps distribute political power 
Não é exagero dizer que se reascende, aqui e alhures, ao menos sob o ponto de vista econômico, um novo localismo, para o qual o empoderamento das comunidades, com descentralização do poder de decisão e dos recursos financeiros, pode significar um antídoto para atenuar problemas políticos, econômicos e fiscais ${ }^{9}$ da contemporaneidade.

Com efeito, é possível perceber, a cada dia de forma mais evidente, que o desenvolvimento econômico e o urbanismo são faces do mesmo processo histórico, conjugados pela natureza dos novos mercados e das contemporâneas formas de viver e habitar.

É fácil identificar o fenômeno mundo afora, principalmente quando se lançam os olhos ao impressionante crescimento asiático.

O vertiginoso desenvolvimento de Singapura, baseado em planejamento centralizado $^{10}$ e coordenação de megaprojetos integrados, é um exemplo desse processo ${ }^{11}$. Outro exemplo é a especial atenção dada às questões urbanas no desenvolvimento chinês, que figuram entre as causas e consequências desse pujante processo. Deng Xiaoping, além da modernização e abertura da economia chinesa na década 70, notabilizou-se por reformas

and creates another independent chack on the unholy coalition. Vibrant communities also help build a sense of identity and purpose in a world where global markets and distant government are sucking out the air from social relationships. They also help diffuse the allure of divisive majoritarian national identities, which tend to also increase friction between nations. Unfortunately, many communities are dysfunctional across the world, primarily because their old economic basis has disappeared" The Third Pilar, New York: Penguin Press, 2019 , p. 325.

${ }^{9}$ Importante esclarecer que Raghuran RAJAN, quiçá pelo perfil liberal da Escola de Chicago, destoa, com alguns argumentos econômicos, das premissas jurídicas adotadas no presente trabalho. Conquanto, em alguns momentos, o economista defenda maior autonomia das comunidades na determinação da produção local, ele tem evidente dificuldade em assimilar regulações locais que possam agravar o nível de liberdade econômica. Exemplificamos esta ressalva com os seguintes trechos de momentos diferentes de seu livro: "Different communities will have different views on business - for example, the kind of business they want operating in their communties. Some will want big-box ratailers like Carrefour or Walmart, while others will prefer small local main-street grocers and shops, even if they cost more. Communities should have the power to determine the nature of local production."Adiante, continua ele: "In the spirit of allowing local decision making, communities could be free to set local licensing norms, but those norms should not be stricter than national norms." Ibidem, p. 306 e p. 387.

${ }^{10}$ A respeito do estrondoso crescimento de Singapura: "In a short span of about 50 years, Singapore has transformed itself economically into a First World economy. This is the result of very conscious public policies that keep both local and global horizon in view. It is the result of a very active interventionist state that has implemented long-term urban development plans." HUAT, Chua Beng. Singapore as a Model in "Worlding Cities: Asian Experiments and the Art of Being Global, 2011, Ed. Ananya Roy and Aihwa Ong., p. 49.

${ }^{11}$ No resumo de Gavin SHATKIN: "The past two decades have witnessed the emergence of a particular urban form throughout Asia, what I will refer to in this chapter as urban integrated mega-projects (UIMs). These are city or urban district-scale integrated development projects built on a for-profit basis, often by a single developer." Planning Privatopolis: Representation and Contestation in the Development of Urban Integrated Mega-Projects in Worlding Cities: Asian Experiments and the Art of Being Global, 2011, Ed. Ananya Roy and Aihwa Ong., p. 77. 
"de baixo para cima", em um mecanismo de manualização das boas práticas experimentadas e testadas em âmbito municipal ou provincial ${ }^{12}$.

O comportamento dos grandes Municípios americanos e europeus não destoa dessa tendência de fortalecimento das cidades em um contexto de revolução tecnológica. Abundam exemplos de políticas públicas locais concentradas na equalização entre dois valores coexistentes: de um lado, o crescimento econômico e, de outro, a busca por qualidade de vida urbana.

No Brasil, desde as Forais até a vigente Constituição Federal, o Município tem exercido papel central, tanto nas políticas públicas de impacto sensível na comunidade, como no planejamento, regulação e fomento das atividades econômicas empreendidas na cidade. ${ }^{13}$.

Essa competência específica, aliada à capacidade técnica, está escorada em uma premissa de fato: apenas localmente é possível aferir e interferir nos microimpactos específicos, verificáveis em uma determinada comunidade.

\footnotetext{
${ }^{12}$ Nos anos 90, o intenso processo de urbanização na China obrigou os prefeitos a adotarem estratégias de crescimento sustentável e planejarem-se a partir de modelos já existentes, como Hong Kong e Singapura. Um exemplo bastante conhecido é o da cidade de Dalian, que evoluiu de uma simples cidade portuária a uma grande metrópole, com estatuto administrativo sub-provincial, em um período de menos de uma década, tendo sido vencedora do UM Habitat Scroll of Honour Award, em 1999. Para Lisa HOFFMAN: "It was also in 1992 that the 'socialist market economy' was formally adopted by the Communist Party. By working through 'the principle of voluntary participation' (Zhao 2001:4), urban modeling motivates local governments to reform their cities and meet economic targets. It was in the context of localized revenue generation and decentralization of decision-making that Mayor Bo iniciated his urbanization strategies and bold greening visions, working with sister-city Kitakyushu, Japan, and emulating practices in Hong-Kong and Singapora." Urban Modeling and Contemporary Technologies of City-Building in China: The Production of Regimes of Green Urbanisms in Worlding Cities: Asian Experiments and the Art of Being Global, 2011, Ed. Ananya Roy and Aihwa Ong., p. 59. Sobre o processo de urbanização chinesa, afirma Joseph STIGLITZ, a seu turno: "China is rapidly urbanizing. An increasing fraction of China's population is living in urban areas, and how they are designed will have enormous effects on quality of life, the efficiency of the overall economy, and environment as China continues to grow. Market forces by themselves will not lead to the creation of livable cities, and there are built-in incentives (both for certain government officials and for private-sector entrepreneurs) for the creation of urban spawls and the design of urban spaces that are counter to the principles underlying livable cities." Creating the Institutional Foundations for a Market Economy in KENNEDY, Daniel; STIGLITZ, Joseph (Org.) Law and Economics with Chinese Characteristics. Oxford: University Press, 2013. p. 91.

${ }^{13}$ As atas registradas pela Câmara Municipal de São Paulo são evidências históricas documentadas e registradas dessa atuação. A título de curiosidade, lembrar a moção dirigida pela Câmara Municipal de São Paulo ao Governo do Estado, onde "própõe seja sustado o andamento de quaesquer planos constructivos que, directa ou indirectamente, interfiram com a remodelação do traçado das principaes vias de acesso ao centro urbano, até que se installe a 'Comissão do Plano da Cidade." Disponível em: http://documentacao.saopaulo.sp.leg.br/iah/fulltext/documentoshistoricos/MOC0001-1936.pdf. Acessado em 02 de junho de 2019.
} 
$\mathrm{O}$ choque entre o que estivera funcionando até há pouco e as novidades referidas acima ultrapassa os conflitos econômicas e políticos e passa inevitavelmente ao campo jurídico, que deve buscar dar solução às contendas e resolução às perplexidades ${ }^{14}$.

Há um natural atrito entre as atividades econômicas consagradas e aquelas novas modalidades ${ }^{15}$. O implemento de inovação pode ser ainda mais conflitivo quando ocorre no âmbito de mercados regulados. Nesses casos, além da natural dificuldade em lidar com os antigos agentes de mercado que são afetados pela obsolescência de suas formas e métodos de prestar serviços, há a perplexidade do Estado, que se percebe na urgente necessidade de adequar os modelos de regulação às novas tecnologias e comportamentos sociais.

O Direito deverá interpretar o meio social sem o antigo binarismo, de categorização e interpretação por fórmulas extremamente rígidas, de modo a passar a atender às atuais expectativas sociais depositadas no Estado e no Direito.

Afinal, por um lado, o uso mais racional dos bens gera economia e competitividade, de outro, extermina modelos empresariais e pode ocasionar canibalização entre agentes econômicos.

O desenvolvimento tecnológico impacta de maneira desigual as diferentes localidades e as esferas da Administração. Por essa razão, entendemos que o Município poderá exercer, como já o tem feito, função primordial no processo de adequação do direito e do estado às novas formas de atividades econômicas, embarcadas em inovações tecnológicas disruptivas, que superam por completo os padrões, métodos e técnicas antes empregados em cada setor.

Para viabilizara solução dessas questões em nível local, é imprescindível delinear os limites das competências legislativas do Município, a fim de se verificar em que

\footnotetext{
${ }^{14}$ Nas palavras de Odete MEDAUAR, “é, indubitavelmente nesse diálogo de princípios, nesse contraponto de princípios, e na sua adaptação aos fatos que o direito encontra sua ordem e sua vida". MEDAUAR, Odete. Poder de Polícia - Origem, evolução, crítica à noção, caracterização in Poder de Polícia na Atualidade. MEDAUAR, Odete; SCHIRATO, Vitor, 2014. p. 24.

${ }^{15}$ Para citar exemplos de impacto nacional, empresas de telecomunicação digladiam com empresas que se valem da conexão de internet para, por meio de streaming, proporcionarem comunicação e entretenimento melhor e mais barato do que o telefone e a televisão. Já sob o aspecto do impacto local, taxistas e motoristas de aplicativos são postos em posições antagônicas, tendo a equivocidade da regulamentação como combustível para o embate nutrido pelo vai e vem das proposições postas em debate.
} 
medida a regulação se justifica diante das competências inscritas na Constituição, marcadamente aquelas postas nos incisos do artigo 30 da Constituição Federal de 1988.

O Direito Constitucional tem neste cenário a função de balizar as competências na divisão de funções entre cada ente federado, de modo a distribuir papéis e impor responsabilidades políticas a cada qual.

A importância ímpar que têm os Municípios no desenho federativo brasileiro é de todos conhecida e revela necessária interpretação dos dispositivos constitucionais que impactam nas formas de atuação deste ente federado no domínio econômico local.

Portanto, discutir a competência municipal nos parece central para a definição do poder regulatório municipal e ratifica a necessidade da presente dissertação.

Essencialmente, como se verá, a dissertação lança olhos ao tema da competência ${ }^{16}$ municipal naquilo que interfere com a ordem econômica, com o condão de dissecar, ao acadêmico ou ao operador do direito, os exatos limites constitucionais da atuação do Município nas funções que interfiram com a ordem econômica.

Nossa proposta de dissertação cingiu-se ao aspecto constitucional e visou desenhar um feixe jurídico-normativo que descreva, de maneira cientificamente organizada, as intersecções entre as competências que dizem respeito à intervenção do Estado na economia e aquelas constitucionalmente atribuídas ao Município.

Para atingir estes objetivos, fez-se cuidadoso levantamento bibliográfico, com pesquisa sobre os estudos existentes, a legislação pertinente, alguma análise sob o método do direito comparado ${ }^{17}$ e singelos estudos históricos sobre repartição de competências entre os entes federados e a capacidade regulatória municipal das atividades econômicas.

\footnotetext{
${ }^{16}$ Para fins deste projeto, adotou-se a definição de competência estabelecida por José Joaquim Gomes CANOTILHO, segundo a qual: "Por competência entender-se-á o poder de acção e de actuação atribuído aos vários órgãos e agentes constitucionais com o fim de prosseguirem as tarefas de que são constitucional ou legalmente incumbidos. A competência envolve, por conseguinte, a atribuição de determinadas tarefas bem como os meios de acção ('poderes') necessários para a sua prossecução. Além disso, a competência delimita o quadro jurídico de actuação de uma unidade organizatória relativamente a outra." Direito Constitucional e Teoria da Constituição, 2002, p. 537.

${ }^{17} \mathrm{~A}$ intenção foi utilizar a metodologia de direito comparado, ainda que de maneira perfunctória, com o intuito de examinar pontualmente algumas experiências internacionais de regulação municipal da atividade econômica sem, no entanto, pretender uma análise puramente internacional, diante da dificuldade na transposição de cenários de federalismos tão díspares.
} 
A análise da jurisprudência nacional, por sua vez, também mereceu atenção do pesquisador, visto que o Supremo Tribunal Federal por diversas vezes se manifestou acerca da competência legislativa e regulatória dos entes federados.

Para o exame do material obtido no levantamento bibliográfico, bem como na elaboração do trabalho de pesquisa, foram utilizados os métodos científicos que se fizerem necessários para cada tipo de análise empreendida no decorrer da nossa investigação acadêmica.

Em primeiro lugar, utilizamo-nos do método dialético, a partir de levantamento bibliográfico, sucedido da contraposição e discussão sobre as diferentes posições doutrinárias - consonantes e dissonantes - sobre o objeto estudado.

Não obstante, o uso de outros métodos, tais como o histórico, comparativo e dedutivo, foi essencial para (i) a análise da evolução histórica do tema, diante da atual e das pretéritas constituições, bem como dos debates constituintes anteriores à Constituição de 1988; (ii) o exame de direito estrangeiro, perante o tratamento jurídico encontrado em outros países, estabelecendo-se, o mais quanto pertinente, paralelo com a situação brasileira; (iii) a verificação dos institutos e princípios constitucionais, mormente no campo do direito constitucional econômico, para compreender o modelo adotado pela Constituição de 1988 no que toca à intervenção do Município na atividade econômica.

As fontes utilizadas, portanto, foram a Constituição Federal, jurisprudência brasileira e internacional e doutrina brasileira e internacional.

Procuramos deixar a bibliografia o mais concisa e precisa possível, sem apontar, genericamente, todo e qualquer manual ou tratado sobre os temas tangenciados no trabalho. Isto resultou na exclusão de muitas obras que, na realidade, não embasam o trabalho em si, mas são obrigatórios para a formação acadêmica de um estudioso do Direito Constitucional Econômico.

Buscou-se, em resumo, encontrar os fundamentos jurídicos da intervenção municipal no domínio econômico, no sentido de traçar seus limites constitucionais. Assim, nossa ambição foi apresentar o tema da intervenção municipal na atividade econômica sob o prisma da repartição de competências, considerando os seus pontos mais importantes, em especial sob a perspectiva de seus limites jurídicos interpretativos, com particular ênfase no interesse público local. 
Os capítulos foram desenhados de modo a sintetizar o silogismo dedutivo que se pretendeu construir para arquitetar o raciocínio geral desenvolvido na dissertação.

No primeiro capítulo, como premissa maior, traçamos a posição ocupada pelo ente municipal na federação brasileira do ponto de vista de suas competências.

No capítulo seguinte, desenvolvemos o tema do interesse público, esmiuçando a questão do interesse local, como conceito aberto regente da competência legislatória municipal.

O terceiro capítulo, mais interdisciplinar, aponta os marcos constitucionais da ordem econômica nos quais se sustentam as formas de atuação do Estado na economia, que constitui, em nosso silogismo, a premissa menor. Nele houvemos de tratar em forma de exemplos e seleção de debates específicos das maneiras pelas quais se dá a intervenção municipal no plano econômico (conclusão), diante das autorizações constitucionais apontadas nos capítulos precedentes, com especial atenção para os limites na interpretação dos parâmetros constitucionais afetos a esta atividade municipal.

Na sequência, a conclusão do mestrado terá o condão de retomar de modo remissivo as ideias desenvolvidas ao longo do texto.

Trata-se, portanto, de silogismo que procuramos fazer para organizar, sob o método dedutivo, o pensamento, a partir de duas proposições que levariam a uma conclusão.

O capítulo I e II seriam a premissa maior e o capítulo III conteria a premissa menor, levando à conclusão nele mesmo exemplificada.

Consignamos que o sumário pode ser entendido como o esqueleto geral do que foi verificado no decorrer da pesquisa. Com isto, os itens poderiam ser desdobrados em subitens, mas, a nosso gosto, os temas poderiam perder a coordenação inicialmente pretendida.

Procuramos, no decorrer desta dissertação, apresentar os conceitos e institutos, bem como os precedentes jurisprudenciais, de maneira a sistematizar o regime constitucional de competências municipais, objetivando, perante situações de impasse sobre competência do governo local, conferir alguma segurança jurídica ao Legislador municipal, à Administração Pública municipal e ao munícipe. 
Neste sentido, ao longo de seus capítulos, a dissertação procurou enfrentar, ainda que sem pretensões exaurientes, as seguintes questões:

(i) Qual a posição ocupada pelo Município na Federação brasileira?

(ii) Quais as competências municipais previstas pela Constituição Federal de 1988?

(iii) Qual a extensão da competência suplementar do Município?

(iv) O Município possui competência suplementar supletiva?

(v) O que é, quais as origens e qual a função do conceito de interesse público em nosso ordenamento?

(vi) O que é interesse local? Qual seu significado?

(vii) O que é ordem econômica e domínio econômico?

(viii) Como o texto constitucional de 1988 estabeleceu a atuação do Estado no Domínio Econômico?

(ix) De que modo ocorre a intervenção estatal na economia?

(x) Há proibição expressa de atuação municipal no domínio econômico?

(xi) Quais os limites da intervenção estatal no domínio econômico?

(xii) No que consiste a ordenação territorial e qual a sua relação com a política urbana?

(xiii) Como ocorre a ação municipal no domínio econômico, de acordo com a experiência brasileira?

(xiv) Em quais circunstâncias o Município poderia atuar como agente de mercado?

(xv) Quais os limites da fiscalização municipal da atividade econômica? 
(xvi) Como é a regulação da atividade econômica pelo Município? Quais seus limites? Qual o posicionamento do STF?

(xvii) De que maneira é constitucionalmente autorizado o planejamento da atividade econômica pelo Município? Qual o entendimento doutrinário e jurisprudencial a este respeito?

(xviii) Como ocorre o fomento municipal da atividade econômica? Qual sua extensão constitucionalmente autorizada?

(xix) Em suma, o Município tem competência para intervir na atividade econômica? Em quais termos? Quais são os fundamentos jurídicos para sua atuação? Quais os limites e a que fim se presta a regulação, o fomento, a fiscalização e o planejamento municipal da atividade econômica? 


\section{CONCLUSÃO}

Diante dos temas apresentados neste trabalho, concluímos que:

1. Desde a primeira revolução industrial, o progresso econômico caminha pari passu com o processo de urbanização. Isso ficou explícito na Londres do século XVIIIXIX e verifica-se, atualmente, em muitas cidades asiáticas, com intensidade avassaladora. Essa urbanização, caso planejada, poderá impactar na forma como a produção de riquezas propaga-se no tempo e influenciar a maneira como a Sociedade urbanizada produzirá riquezas e apropriar-se-á do excedente gerado.

2. Além disso, está hoje em andamento a quarta revolução industrial, caracterizada pela supressão de intermediários, extinção de antigos mercados e criação de novos. A dinamização dos fluxos e o assim chamado "compartilhamento de bens" impactam sobremaneira as cidades, onde a infraestrutura urbana é especialmente demandada e o bens particulares passam a ter função econômico-produtiva, transmutando-se em verdadeiros bens de produção.

3. Nessa linha de ideias, mostra-se coerente deduzir a necessidade por um ator capaz, ao mesmo tempo, de (i) intervir microscopicamente; e (ii) atentar para os impactos gravemente locais da nova economia. No Brasil, o ente federativo vocacionado para atender a estas demandas eminentemente locais é o Município.

4. O Município brasileiro tem características próprias do modelo de Federação que se desenvolveu por aqui. Como decorrência, cultivou-se uma doutrina endêmica em nossas estruturas: o Municipalismo. Tal doutrina identifica-se tanto na forma como foi concebido o ente municipal, como em um certo proselitismo pela descentralização político-administrativa-orçamentária.

5. Sopram, aparentemente, nesta e noutras partes do planeta, renovados ventos localistas. Em um momento em que o Estado Nacional e os grandes conglomerados econômicos ganham, na prática, poderes quase divinos (a partir da tecnologia da 
informação, processamento de dados e inteligência artificial), defende-se, aqui e acolá, o empoderamento das comunidades, com descentralização de recursos financeiros e do poder decisório.

6. Ao radiografar o federalismo, desde suas origens, é possível retirar alguma lógica econômica em seu desenvolvimento. Essa afirmativa sustenta-se no fato de que a divisão dual de competências, marcada pelo início da Federação americana, esteve em linha com o laissez faire do liberalismo econômico do século XIX, deixando, no entanto, de ser efetiva contra as crises e turbulências que pulularam no início do século XX.

7. Como consectário das necessidades de maior participação do Estado na economia (e.g. New Deal), o federalismo dual foi sendo superado por uma lógica de cooperação entre os níveis federativos, com consequente predomínio dos poderes centrais. A isso seguiu-se uma tendência de creditar ao poder nacional uma maior capacidade técnica e estrutural para intervir na Sociedade.

8. No Brasil, o Município esteve à deriva das jusantes e montantes dos regimes que se interpolaram por aqui. A Constituição Imperial de 1824, centralizadora, embora adotasse o Estado Unitário, conferia destaque para as vilas e cidades na resolução dos assuntos locais; enquanto a Constituição Republicana de 1891 era federalista por desagregação (centrífuga) e formalmente garantidora de uma espécie de autonomia municipal que só não foi exercida de fato em razão de nossa tradição centralizadora e coronelista. A Constituição de 1934, por sua vez, estabeleceu "rendas próprias" aos Municípios, mas preferiu favorecer a União na repartição de competências. Já no texto constitucional de 1937, vislumbra-se a diminuição momentânea da importância e autonomia municipal em razão do Estado Novo, ao passo que a Constituição democrática de 1946 previu o municipalismo corporificado na tríplice autonomia: política, administrativa e financeira. Adiante, todavia, os atos institucionais de 1967 e 1968 fragilizaram em grande medida as garantias outrora franqueadas, somente retomadas, de maneira significativa, com a Constituição Federal de 1988, quando a autonomia municipal encontrou sua preamar. 
9. Conquanto a Constituição em vigor preceitue a autonomia municipal em sua tríplice matriz (política, administrativa e financeira), houve um considerável movimento de centralização no que toca à distribuição de competências. Sem embargo de haverem sido incluídas mais matérias no rol de competências concorrentes (modelo cuja influência remonta à Constituição Alemã de 1949), os diplomas nacionais tenderam sempre a eclipsar o campo de atuação próprio dos entes subnacionais, mediante leis e atos normativos que flertam com a exaustividade. Além disso, relativamente às competências privativas da União, houve um considerável acréscimo em relação àquelas prevista na Constituição de 1967.

10. Desse modo, ficam claras duas coisas (i) a distribuição concorrente de competências, associada a um extenso rol de competências privativas da União, deflagra, paulatinamente, um processo de centralização contínua; e (ii) o federalismo de cooperação, no Brasil, é algo que depende dos fluxos e influxos da centralização ou descentralização vivenciadas na prática, a partir das plataformas políticas e da interpretação jurisprudencial.

11. Além disso, sequer a posição ocupada pelos Municípios no Brasil é objeto de consenso. Viceja, debalde, em nossa doutrina, longevo debate sobre se o Município é ou não um ente federado. Enquanto alguns acenam negativamente, pela ausência de representação municipal no Senado Federal ou Poder Judiciário municipal, outros reputam cristalina a redação do caput do art. $1^{\circ}$ da Constituição de 1988 , o qual dispõe que a República Federativa do Brasil é formada pela união indissolúvel de Estados, Municípios e Distrito Federal.

12. A par dessa questão, há quem aponte, outrossim, que o ente municipal, tal como concebido em nosso sistema federativo, é significativamente engessado do ponto de vista institucional, uma vez que não pode, livremente, escolher seu modelo de organização, a exemplo dos Estados Unidos da América, onde vigora o modelo de Charter Cities. Essa crítica parece estar em consonância com o apelo para um maior experimentalismo institucional, de que poderiam ser laboratórios os muitos Municípios brasileiros, os quais, a bem dizer, gozam de autonomia constitucionalmente assegurada e competência para legislar sobre assuntos de interesse local. 
13. Recentes julgados do Supremo Tribunal Federal vêm nesse sentido (e.g. ADI $\mathrm{n}^{\circ}$ 4.060), ao perceber que a federação não é estática e, justamente em sua dinâmica, pode a Corte prestigiar iniciativas locais para "promover o pluralismo nas formas de organização política" e "tentar experimentos econômicos e sociais sem risco para o resto do país".

14. Essa dinâmica do federalismo representa uma verdadeira "cultura" e implica, de outro lado, na definição precisa de competências de cada ente federado. Nesse diapasão, estabelecer as atribuições de cada qual é tarefa exigida pelo princípio da segurança jurídica para (i) garantir a limitação do Poder, por meio de regras formal e materialmente válidas (além de compreensíveis e previsíveis), capazes de evitar conflitos federativos; e (ii) impor responsabilidades e funções a cada ente federativo, em estruturas de organização do Estado articuladas por tarefas prescritas em regras de ação.

15. Ao contrário do que ocorre no federalismo dual, a repartição no federalismo cooperativo segue regras de competência distribuídas entre administrativas (exclusivas/privativas ou comuns) ou legislativas (privativas, concorrentes, suplementares ou supletivas), além, claro, das competências implícitas.

16. Em nosso estudo organizado sobre a distribuição de competências na Constituição de 1988 pudemos perceber, sobre as atribuições de União e Estados, o seguinte: (i) as competências administrativas exclusivas da União apontam para um objetivo de tratamento jurídico único, homogêneo em todo o território nacional para determinadas matérias (e.g. exercer monopólios constitucionais, emitir moeda, administrar as reservas cambiais do país, fiscalizar as operações de natureza financeira, especialmente as de crédito, câmbio e capitalização, bem como as de seguros e de previdência privada); (ii) as competências administrativas comuns tem a ratio de viabilizar a cooperação entre os entes federados, visando o equilíbrio na somatória dos esforços alocados nos respectivos domínios, tal que a própria constituição dá os meios para coordenar as iniciativas e funções de cada ente federado, ao dispor que a cooperação entre eles poderá ser regulamentada por Leis Complementares; (iii) dentre as competências legislativas privativas da União, 
destacamos aquelas que versam sobre direito civil, comercial e do trabalho; águas, energia, informática, telecomunicações e radiodifusão; além de trânsito, transporte e diretrizes da política nacional de transportes, que representam os maiores pontos de intersecção com as competências municipais para intervenção no domínio econômico; (iv) na competência concorrente, cabe à União estipular normas gerais, enquanto que aos Estados incumbe complementá-las e regulamentá-las, no exercício da competência suplementar - salvo quando inexistir lei federal, hipótese em que Estados podem exercer a competência legislativa plena, para também instituir normas gerais, em sua competência suplementar supletiva; e (v) além das competências expressamente enumeradas e remanescentes (residuais), promanam, das três esferas, competências implícitas, que decorrem logicamente dos poderes reservados ou expressos.

17. Quanto às competências municipais, verificamos que, muito antes de haver-se atribuído aos Municípios brasileiros status constitucional inaudito em outra parte do mundo, as tarefas atinentes ao específico interesse local foram sempre e sempre de sua alçada, como célula política do organismo federativo. Assim, podemos divisálas em competências (i) administrativas explícitas próprias (i.e. serviços públicos de interesse local; educação infantil e ensino fundamental; atendimento à saúde da população; ordenamento territorial, mediante planejamento e controle do uso, do parcelamento e da ocupação do solo urbano; proteção do patrimônio históricocultural local; e, atipicamente, a competências administrativa própria na área de segurança pública); (ii) administrativas explícitas comuns (e.g. proteger o meio ambiente e combater a poluição em qualquer de suas formas; fomentar a produção agropecuária e organizar o abastecimento alimentar; promover programas de construção de moradias e a melhoria das condições habitacionais e de saneamento básico; combater as causas da pobreza e os fatores de marginalização, promovendo a integração social dos setores desfavorecidos; dispensar às microempresas e às empresas de pequeno porte, assim definidas em lei, tratamento jurídico diferenciado, visando a incentivá-las; promover e incentivar o turismo como fator de desenvolvimento social e econômico; e promover e incentivar o desenvolvimento científico, a pesquisa, a capacitação científica e tecnológica e a inovação); (iii) administrativas implícitas; (iv) legislativas enumeradas (i.e .legislar sobre assuntos de interesse local; instituir taxas, contribuições de melhoria e impostos de sua 
competência; criar, organizar e suprimir distritos, observada a legislação estadual; e organizar e prestar, diretamente ou sob regime de concessão ou permissão, os serviços públicos de interesse local, incluído o de transporte coletivo, que tem caráter essencial); (v) legislativas suplementares, apenas, "no que couber”, para suplementar legislação federal ou estadual nas matérias concorrentemente atribuídas pela Constituição (tais como direito econômico; produção e consumo; ou proteção do meio ambiente e controle da poluição); e, finalmente, (vi) legislativas supletivas, de modo que o Município supre eventual omissão da União para instituir normas gerais, suspendendo-se os efeitos no caso de superveniente cessação da inércia federal.

18. Eis então um panorama da distribuição constitucional, já de onde se podem localizar as muitas e variadas formas pelas quais o Município, observadas as garantias individuais, intervém na ordem econômica. Surdem, nesse passo, dois arrimos sobre os quais deverá lastrear-se a imisção de um ente municipal no âmbito da economia local: interesse público e interesse local. Desde aí é possível concluir-se que o requisito para tanto é atendido quando há interesse (público) local apto a sustentar referida atuação.

19. Relativamente ao primeiro requisito, interesse público, pudemos constatar, a partir das origens da ideia de interesse geral, no esboroar do Antigo Regime, que ele surgiu como sucedâneo à ancestral deontologia meramente religiosa e dogmática, insuficiente em um contexto de crescente laicização do Estado. Mais do que isso, o interesse geral prestava-se à ideia de contraequivalência, segundo a qual, em uma perspectiva realista e contratualista sobre a natureza do homem, haveria de conceberse um contravalor apto a refrear as paixões humanas (e.g. desejo por poder - libido dominandi - e ânsia por dinheiro - auri sacra fames). Desta feita, entre um mero apelo à coerção repressiva e a efetiva mobilização harmonizadora das paixões humanas, esta última saída - menos dependente da indulgência excessiva ou crueldade desmesurada do Príncipe - despontou como dogma do liberalismo econômico do século XIX, podendo ser verificada, ainda antes, nas concepções sobre separação de poderes no Constitucionalismo do século XVIII.

20. O interesse geral, como razão de Estado, ganha dimensões jurídico-normativas. Momento a partir do qual começa a tormentosa tarefa de definir os contornos desse 
conceito multifacético, que é absorvido por nosso ordenamento como interesse público. Interesse público é, para o Direito Administrativo, a um só tempo, fundamento e objetivo da gestão pública. Por essa razão, não foram poucos aqueles que tentaram defini-lo.

21. Diante das dificuldades em precisar o conceito, sobejam, ainda agora, críticas à ideia de que a atuação do Estado na Sociedade e, mais especialmente, na economia, possa sustentar-se na existência de uma supremacia do interesse público sobre o privado. Ao revés, entendem estes autores que a ordem constitucional atualmente em vigor afirma a primazia da pessoa humana sobre o Estado, tendo erigido os direitos fundamentais como pedra angular de nosso sistema. Ao lado desta doutrina, ressoa uma outra que conserva a supremacia do interesse público, discernindo entre interesse meramente particular e interesse da pessoa enquanto membro da Sociedade. Nessa perspectiva, em cada indivíduo repousaria um interesse pessoal de que se preservem os valores mantenedores da coesão social e do bem-estar da coletividade. Os direitos fundamentais, segundo essa última visão, colocar-se-iam como limites à atuação estatal.

22. Novos aprimoramentos vão surgindo. Uns para matizar o princípio, denominando-o "preponderância do interesse público" e submetendo-o à ideia de "minimização dos sacrifícios" (mediante a ponderação a partir do critério da proporcionalidade). Enquanto outros para situar os direitos fundamentais e a dignidade humana como "ponto de partida geral", condição apenas necessária para concretizar o interesse público, lido não mais como conceito difuso, mas positivado em uma constituição democrática e soberana, que, por sua vez, não se satisfaz apenas com direitos de natureza negativa; ao contrário, obriga que o Estado, antes meramente repressor, também preste serviços e regule a economia.

23. Essa discussão doutrinária dá-se, toda ela, tendo como pano de fundo uma mudança de paradigma na relação entre Estado e Sociedade, num contexto em que se sofistica essa interação. Na intervenção do Estado na economia contrapõem-se interesses difusos (i.e. que "dizem respeito à qualidade de vida global") e interesses especiais (i.e. titularizados por grupos sociais bem organizados). Assim, espera-se que o Poder 
Público articule os diferentes interesses dentro da Sociedade (i.e. públicos, especiais e difusos) como "mediador ativo", evoluindo o princípio da supremacia do interesse público para significar uma "preponderância do interesse público", que interdite interesses particulares prejudiciais ao coletivo e que jamais descure dos interesses públicos difusos, os quais não são orquestrados por grupos de pressão. Essa concertação harmônica entre interesses públicos e privados tem precedentes que remontam à doutrina americana do National Interest, surgida nos anos 30 do século passado, quando se concebeu um interesse unitário e transcendental, estruturante e concitador dos impulsos econômicos privados em vista de um interesse coletivo, nacional. O mesmo amálgama público-privado é verificável no contexto atual de muitos países asiáticos que apresentam elevado grau de progresso econômico.

24. Vimos, enfim, que, com o tempo, vão surgindo novas e diferentes concepções sobre a forma de traduzir a ideia de interesse público. Atravessou incólume, todavia, a percepção de que a todos sempre interessará o bom convívio comunitário, do indivíduo entre os seus: pleno em suas individualidades, mas, simultaneamente, em comunhão com a coletividade. Nessa senda, se é difícil, por um lado, compreender o interesse público em sentido ampliado, em uma dimensão local, por outro, será mais fidedigna a interpretação sobre o que sejam os anseios que o caracterizam. Em outras palavras, quanto mais próximo da comunidade, mais autêntica e genuína será a compreensão que o gestor público fará do interesse geral, já que o administrador ou legislador local é capaz de verdadeiramente auscultar os desejos sociais de seus conterrâneos, em um ambiente naturalmente mais democrático e participativo.

25. Procuramos, por conseguinte, avaliar adequadamente a noção de interesse público e buscar seus limites. Pontuamos, inicialmente, que interesse público não corresponde à somatória dos apetites individuais. Além disso, o uso do termo "interesse" pelo Constituinte, seja interesse público, coletivo, social ou local, é uma técnica normativa de que lança mão para condensar distintos valores derramados no texto constitucional, motivo pelo qual o intérprete deve buscar, no conjunto e contexto da Carta, os valores protegidos por cada "interesse". Por fim, a título de delimitação descritiva, apresentamos a clássica distinção entre interesses públicos primários e secundários. 
26. Em um segundo momento, valemo-nos das lições sobre conceitos indeterminados em geral, tais como probidade, moralidade, eficiência, boa-fé e, por que não, interesse público. A melhor doutrina a respeito aponta para o fato de que qualquer que seja o conceito indeterminado, sempre será possível identificar nele um halo, ou núcleo, conceitual. Assim, apenas surgiriam dúvidas hermenêuticas para fora da "zona de certezas". No caso de interesse público, portanto, temos três zonas: de certeza positiva, de certeza negativa e de penumbra, ou incerteza. A zona de incerteza é onde ocorre a efetiva construção do conceito desde o caso concreto, a partir da interpretação do texto face à realidade cambiante e multifacetada.

27. Por fim, demonstramos que o conceito pode ser compreendido por uma visão bipartida, que o divisa entre interesse público em sentido amplo (mínimo ou fraco) ou interesse público em sentido estrito (forte). O primeiro ocorre sempre que o Direito, de modo geral, atribui ao Estado o dever de resguardar certo valor, legitimando, como consequência, qualquer atuação do Poder Público. Assim considerado, serve o conceito, quando menos, para delimitar um pressuposto negativo de validade do ato estatal, donde é vedada qualquer ação administrativa que atenda a finalidade diversa.

28. A segunda compreensão, sentido estrito (ou forte), ocorre quando a regra jurídica qualifica o interesse público, exigindo-o, devidamente motivado, para uma determinada atuação concreta do Poder público. Explicitamente (quando utiliza uma expressão análoga a interesse público, e.g. o "relevante interesse coletivo" a autorizar exploração direta de atividade econômica pelo Estado) ou implicitamente (por meio de uma atribuição discricionária, e.g. art. 174 da CF). Nesses casos estamos diante de pressupostos positivos de validade da atividade do Estado, especialmente recomendáveis para instituir proibições, limitações ou requisitos às atividades privadas (em suma, para efeitos de nosso recorte, para intervir na economia).

29. Superado o estudo sobre um dos pilares sobre os quais se apoia a intervenção municipal no domínio econômico, passamos para o outro, qual seja, a interpretação do que venha a ser "interesse local". Iniciamos esclarecendo que há dois tipos distintos de limites pelos quais o poder superior restringe e regula o poder inferior: relativos ao conteúdo ou à forma. O primeiro representa os limites materiais e o 
segundo os limites formais. Quando um município desborda de sua atribuição federativa e invade competência de outro ente estamos diante de uma inconstitucionalidade de natureza formal. Nada obstante, para o específico estudo da intervenção municipal no domínio da economia, referida locução nos conduz a pelo menos duas dimensões de interpretação, material e formal, já que deverão ser contempladas duas exigências impostas pelo legislador constitucional simultaneamente: (i) haverá de incidir um interesse tutelável pelo Estado e, nesse sentido, um interesse que não seja puramente particular (limite material); e (ii) ele deverá ser predominantemente local (limite formal). Daí ler-se interesse (público) local.

30. Com efeito, "interesse”, nesse caso, pode ser público, privado, difuso, coletivo, desde que tenha uma dimensão comunitária, apta a justificar a atuação do Município. Ou, em outras palavras, o "interesse”, nesse caso, abrange quaisquer legítimos interesses, públicos ou privados, especiais ou difusos (ambas classes de direitos transindividuais), que surjam, operem-se e realizem-se em âmbito local, desde que justifiquem regulação do Estado.

31. O termo "local", a seu turno, cumpre a função de definir o âmbito de incidência da competência do Município. Sobre essa específica delimitação grassam incontáveis dúvidas e debates. Exceção feita a precedentes jurisprudenciais arqueológicos, desde as constituições pretéritas, quando vigorava o termo "peculiar interesse", sempre prevaleceu na doutrina a interpretação de que a competência para tratar de temas de interesse local referia-se a situações em que "predominam" interesses locais, dado que "não há interesse municipal que não o seja reflexamente da União e do Estadomembro".

32. Verificamos, ainda, que o constituinte fez uma escolha muito clara ao empregar, também aqui, um conceito aberto para definir algo que, tirante as zonas de certeza positiva ou negativa, somente poderá ser acuradamente apreciado na perspectiva casuística. Vale dizer, somente ao contrastar fatos, capacidade técnica e texto constitucional poder-se-á extrair, do art. 30, I, da Constituição Federal, a norma justa para o caso concreto. Malgrado haja quem defenda (i) que a competência municipal descrita no referido inciso é residual em face das competências dos demais entes 
federados; ou (ii) que estariam albergadas na locução "interesse local", indistintamente, toda a gama de interesses que gravitam sobre a órbita das localidades (pertinente, assim, uniformemente, a toda e qualquer municipalidade), parece-nos que o constituinte originário visava o oposto. A teleologia da cláusula aberta mirava, em nosso ver, o desiderato inverso, ou seja, teria buscado o legislador constitucional uma forma de encilhar um feixe de competências que variam conforme as "peculiaridades" de cada Município. Assim, face à disparidade que há entre os municípios brasileiros, interesse local, enquanto conceito aberto, somente seria aferível a partir das especificidades e circunstâncias inerentes a cada localidade.

33. Nessa toada - nada obstante, ao se depararem com conflitos federativos, os Tribunais, regra geral, prestigiem as competências da União - alguns refrescados precedentes do Supremo Tribunal Federal, nos últimos anos, apontam no sentido de acolher interpretação que não tolha a competência dos entes menores. Desse modo, nossa Suprema Corte parece caminhar na direção de (i) presumiras capacidade e competência dos entes subnacionais (presumption against preemption); e (ii) exigir que as normas gerais indiquem, de maneira clara, precisa e cogente (segundo critérios de proporcionalidade - necessidade, adequação e razoabilidade), quando não puderem, Estados ou Municípios, legislar sobre determinada matéria de impacto regional ou local (clear statement rule). Caso contrário, não se exclui, aprioristicamente, a competência de outros entes para regulação específica ou peculiar.

34. Muito embora esteja o Supremo Tribunal Federal apoiando esses precedentes em doutrina e jurisprudência americanas, a compreensão esposada pelo pretório excelso nada mais é do que corolário do princípio da subsidiariedade em sua dimensão vertical. O princípio da subsidiariedade, cujas origens jurídicas remontam à Europa do início do século XX, pode ser compreendido tanto em sua perspectiva horizontal, na relação Estado e Sociedade, quanto na perspectiva vertical, em referência às autonomias constitucionalmente qualificadas, descentralização e repartição de competências no federalismo.

35. Existe, em certa medida, uma confluência entre essas duas dimensões do conceito, já que o princípio da subsidiariedade pretende um modus in rebus na relação entre 
Estado e Sociedade. Quando demasiadamente íntimos, acabariam por marginalizar o indivíduo; enquanto que um rompimento artificial entre eles seria hostil à construção de estruturas que promovam o consenso e o pluralismo. Em Sociedades com sólida base comunal, esse dilema sobre a relação entre Poder Estatal e Indivíduo é equacionado a partir de uma interação entre poder central e poderes periféricos, mediante ideias regionalistas e municipalistas.

36. Apresentamos no trabalho a polêmica que circunda o tema da subsidiariedade horizontal, a qual poderia, no limite, justificar um Estado aquém do imprescindível para a construção de uma Sociedade livre, justa e solidária. A controvérsia, em nosso entender, tem um quê de ideológica, pois sempre haverá um aspecto comissivo da subsidiariedade, de tal modo a, na incapacidade dos atores privados,obrigar uma ação do Estado. Além disso, em certa medida, prescindimos desta discussão para podermos afiançar que a subsidiariedade vertical é autônoma em relação à subsidiariedade horizontal. Pode soar inusitado descolá-las, já que, inicialmente, uma provém da outra. Pareceu-nos, todavia, que a subsidiariedade aplicada no estudo do federalismo pode recrudescer a valia do interesse público na ordem jurídica, uma vez que, em âmbito municipal, a proximidade entre Estado e Sociedade é mais tangível. Ademais, a obrigatoriedade da gestão democrática das cidades sinaliza para uma melhor percepção, na prática, dos múltiplos interesses em jogo no ambiente da comunidade urbana.

37. Consequentemente, a incidência implícita do princípio da subsidiariedade em nosso federalismo foi tema especialmente relevante para este trabalho, (i) a uma, porque já tem constado de recentes julgados do Supremo Tribunal Federal para reconhecer, no âmbito da repartição constitucional de competências federativas, que o Município detém primazia sobre os temas de interesse local, nos termos do disposto no art. 30, I, da Constituição; (ii) a duas, porque revela vetor interpretativo na compreensão do interesse local. A repartição vertical de competências no federalismo segue uma racionalidade de respeito e preservação das diversidades histórias e individualidades locais, proteção das minorias, proteção da liberdade, reforço da democracia e eficiência do modelo de gestão política e administrativa, viabilizando decisões mais técnicas, transparentes, equilibradas e sindicáveis. Deste modo, o federalismo pode 
ser entendido como a concretização do princípio da subsidiariedade na organização do Estado.

38. Por fim, apresentamos, como sugestão, a doutrina alemã da lealdade federativa. A qual implica, na conduta dos entes federados, repercussões positivas e negativas. Comina, por um lado, consequências comissivas (tais como deveres de ajuda, apoio, informação, consulta, coordenação e cooperação entre eles). Por outro lado, pressupõe limitações ou barreiras ao exercício de suas competências que, ainda que textualmente asseguradas, no caso concreto, não atendam (pelo aspecto forma ou pelo aspecto conteúdo) ao fundamento constitucional da boa-fé objetiva entre entes federados.

39. Ficou claro até aqui que nas comunidades locais, sobretudo nas urbanizadas, a forma como interagem Estado e iniciativa privada é decisiva para a conformação do mercado, enquanto "locus artificialis" onde se desenvolvem atividades de troca e produção. No território do Município são catalisadas interações econômicas e condensados interesses (tanto públicos, quanto privados), imputando-se-lhe papel essencial nesse processo. A interação dos interesses privados com o Estado e, consequentemente, com o Direito não é de antagonismo, mas, antes, de interdependência, já que a produção econômica influi na elaboração das normas e o Estado, através do ordenamento jurídico, fornece ao mercado os elementos de previsibilidade e segurança, tão caros ao desenrolar das atividades econômicas.

40. Deste modo, ao Estado incumbem, na atualidade, as complexas atribuições de estimular e garantir o desenvolvimento, em todos seus aspectos, além de arbitrar diferentes demandas, a partir da melhor concepção de interesse público. Para esse mister, o Direito, antes predominantemente prescritivo de sanções negativas e repressivas, evolui para dar maior ênfase à organização e condicionamento de comportamentos desejados, manejado como instrumento promocional, através de sanções positivas ou premiais. Oferece, destarte, ferramental normativo para que o Estado dê cabimento apropriado a uma miríade de atribuições que lhe foram sendo outorgadas pelas realidades social e econômica, no sentido de ordenar, regular, policiar e fomentar, além de atuar como agente de mercado. 
41. Nesse cenário em que ao Estado incumbem tantas e difíceis atribuições, o Município brasileiro, efluência local desse Estado, com relevante grau de participação no sistema federativo, está, por definição conceitual, encarregado de ocupar-se de questões de jaez econômico, desde que sensíveis aos cotidiano local, as quais também têm evoluído concomitantemente ao complexo desenvolvimento da Sociedade.

42. Para demonstrar essa interação e justificá-la diante das prescrições constitucionais, recorremos, primeiramente, à definição concreta do que se pode entender por domínio econômico e ordem econômica. O primeiro percebido como campo de atuação - pública e privada - em que se desenvolvem as atividades econômicas (daí falarmos indistintamente de intervenção ou atuação/participação do Estado na economia). O segundo conceito compreendido como o arranjo jurídico-institucional conformador do sistema econômico, que traduz o modelo econômico havido numa determinada sociedade.

43. Em nosso caso, portanto, a Ordem Econômica, fundada juridicamente pela Constituição Econômica, é atrelada umbilicalmente ao Estado, cuja origem teórica também encontra exsurgência no texto constitucional. Isto significa que, quando se está diante da Constituição Federal, visualizam-se, a um só tempo (i) a fundação dos preceitos jurídicos da Ordem Econômica e (ii) os papéis, ou competências, conferidas ao Estado nesta interface com a economia. Podemos também falar de uma Ordem Econômica Municipal, no qual incidem não apenas os princípios tratados no art. 170, $\mathrm{CF}$, mas também outros, como, por exemplo, aqueles que dizem respeito à política urbana (arts. 182 e 183, CF), os quais visam, sob esse prisma, regular o impacto das atividades econômicas locais no cotidiano do cidadão.

44. Como mencionamos, inobstante as atribuições de que goza o Município hoje, ainda há quem, escorado no argumento do engessamento institucional, critique o modelo federativo adotado pelo constituinte brasileiro. De fato, um modelo que não confira flexibilidade e ductibilidade na forma como os agentes políticos poderão adequar-se às cambiantes demandas econômicas e sociais, de algum modo, inviabilizará o fator que, ao longo de todo o histórico capitalista, fez com que esse modelo econômico prosperasse sobre os demais: o aperfeiçoamento a partir da experimentação ou, para 
o setor público, policy learning. Nesse mesmo sentido, surgem teorias econômicas que defendem a viabilização de focos de desenvolvimento regidos por estruturas locais, onde haja conjunção entre Estado e capital para desenvolvimento econômico organizado, aptos a descobrir e implementar novas regras, novas ideias de como estruturar interações econômicas, em uma lógica de competição entre entes federados.

45. A nosso ver, o modelo federativo brasileiro já atende a essa perspectiva. Parece haver um certo fetichismo institucional ou legislativo, pois é possível extrair do nosso sistema constitucional a autonomia e o interesse local (como regra de competência formulada em um enunciado genérico), as quais possibilitam que o intérprete consiga aplicar a lei de maneira a se adequar às demandas de cada localidade. Assim é que, na dinâmica econômica e social em que está inserida a federação brasileira, depende do intérprete uma certa "cultura" de perceber, em nossa estrutura constitucional, a competência do Município, lastreada propositadamente numa regra de conceito aberto, como possível solução para o tão desejado experimentalismo competitivo sugerido acima.

46. Nesse sentido, no decorrer de nossos estudos, ao aprofundar o tema das competências municipais, notamos que também a conceito aberto de interesse público contém a semente para solucionar o problema de engessamento do governo local, aliado à tendência, inclusive jurisprudencial, de fortalecimento da federação, aplicando-se cada vez mais recorrentemente o princípio da subsidiariedade em seu sentido vertical, prelúdio de uma visão que contemple o Município como agente de transformação econômica.

47. A multiplicidade de interesses em diálogo no ambiente urbano - sejam estatais, coletivos, dos agentes econômicos (e.g. promotores imobiliários e aplicativos de mobilidade) ou dos proprietários - revelam-se como verdadeiros interesses locais e, por isso mesmo, justificam a atração da competência municipal para sua influência como regulador, em sentido amplo. O Estado-município terá funções de organizar a economia municipal, de um lado preservando um bom nível de competitividade, de outro minorando externalidades negativas, dado que a interação urbanística 
transparece muitos aspectos às vezes conflitantes entre qualidade de vida e relações econômicas.

48. O município é a concretização de uma riqueza coletiva, mas cujas apropriações são extremamente assimétricas e desorientadas. Por essa razão, surge a imprescindível capacidade regulatória de um ente que, municiado pela Constituição e pelos diplomas urbanísticos nacionais, deve orientar o desenvolvimento econômico local, de maneira a evitar o crescimento das disparidades internas. Deve, outrossim, preservar os interesses difusos, ao coibir o abuso do poder econômico em todas suas formas. De outro lado, também deve fomentar organizadamente os interesses econômicos, comungados com os interesses coletivos. Portanto, da mesma forma, há de haver fomento pelo gestor municipal, mediador dos interesses, no sentido de que organiza, arbitra, prospecta e efetiva os interesses comuns da sociedade.

49. Para demonstrar como se dá essa interação entre o rol de competências atribuídas constitucionalmente aos entes locais e as formas de intervenção estatal na atividade econômica, fizemos um estudo exemplificativo de algumas materializações desta atividade municipal, valendo-nos, quando necessário, de alguns preciosos conceitos de Direito Econômico, Administrativo, Urbanístico, Ambiental, Financeiro, Tributário e do Consumidor.

50. Em um primeiro momento, perquirimos sobre as competências municipais para atuar diretamente na atividade empresarial, como agente de mercado. Diante da redação do art. 173, verificamos que a Constituição de República prescreve dois requisitos alternativos para que o Estado empreenda diretamente na seara econômica, sempre em observância à prescrição legal. Reservada à União a defesa da segurança nacional, caberá aos Municípios apenas o exercício direto das atividades econômicas de relevante interesse coletivo. Ademais, esse específico interesse, a autorizar que o Município se enverede diretamente nas atividades econômicas, deve ser local, conforme regra insculpida no art. 30, I, da CF.

51. Ao passar ao estudo da regulação municipal, lembramos que Constituição Federal de 1988 outorgou competência privativa à União para legislar em áreas cruciais à regulação da atividade econômica, (e.g. art. 22, I, IV, IX e XI), bem assim, 
competência legislativa concorrente em matérias de igual espécie (e.g. art. 24, I, V, VI, VII, VIII e IX). Daí haver alguma preponderância da União, que tendeu, até recentemente, a obliterar o papel dos entes federados subnacionais, com certa conivência de nossos Tribunais. Vemos que boa parte das questões atualmente postas sob escrutínio do direito econômico, impactam, às vezes de forma preponderante, matérias de interesse local, afetas à realidade de cada cidade, sendo difícil conceber a suficiência de uma regulação de visão ampliada, míope às demandas e complexidades eminentemente locais. As novas formas de interação econômica, dentre as quais está a denominada economia compartilhada, exemplificam esse panorama de inovações disruptivas. Afinal, para além da transformação dos espaços e condições de troca, os efeitos oriundos de empresas como Uber ou Airbnb refletemse diretamente sobre matérias de âmbito municipal (e.g. políticas de transporte e habitação). A maior parte das "megacidades" pelo mundo, que sofrem com estes impactos, tem regulado os setores de maneira individual e específica, o que denota a importância de uma visão particularizada para cada ambiente municipal. Além disso, a importância dos dados coletados por essas plataformas digitais para as políticas públicas de natureza urbana é evidente, o que justifica uma atuação concertada entre Município e empresas de tecnologia para compartilhamento/disponibilização de dados com o poder público.

52. Regular hoje é bastante diferente de regular no início do século XX, quando isto significava dar mais liberdade ou aperfeiçoar o funcionamento dos mercados, minorando suas imperfeições. Assim, a mera regulação da troca (quando a troca está eficiente, prescinde-se do Estado) não coaduna com momentos escassez de infraestrutura e recursos naturais, bem como aumento das demandas por bens e serviços. Assim, do foco na troca, passamos ao foco no acesso e compartilhamento. No contexto da cidade, a escassez é evidente, como também é óbvio que o compartilhamento da infraestrutura urbana sempre foi uma necessidade. Assim, temos que, ao regulador, cabe garantir acesso digno a bens/serviços que sejam identificados como imprescindíveis ou essenciais aos munícipes. Regular o espaço urbano significa, outrossim, regular a economia municipal, nos aspectos que dizem respeito ao interesse da coletividade local. Destarte, é possível dizer que onde há direito urbanístico, há direito econômico. Não à toa que, na Constituição Federal de 1988, o capítulo da política urbana está inserido na seção sobre a Ordem Econômica. 
53. O Supremo Tribunal Federal, quando confrontado sobre os limites constitucionais da atuação municipal no domínio econômico, acabou dedicando duas de suas cinquenta e seis súmulas vinculantes. A Súmula Vinculante $n^{\circ} 38$ determina que é competente o Município para fixar o horário de funcionamento de estabelecimento comercial (ressalvados horários bancário) por se tratar de assunto de interesse local, à luz do disposto no art. 30, I, da Carta Magna. Do mesmo modo, entende o STF que aos Municípios é dado dispor sobre o tempo de atendimento nas agências localizadas em seu território.

54. A Súmula Vinculante $n^{\circ} 49$, por outro lado, fixa a tese de que ofende o princípio da livre concorrência lei municipal que impede a instalação de estabelecimentos comerciais do mesmo ramo em determinada área. A despeito de, sob uma primeira vista, parecer que os princípios constitucionais da livre concorrência e da livre iniciativa econômica são postos como valores superiores às razões de interesse público municipal para regulação do espaço urbano, na realidade, houve, para elaboração da Súmula Vinculante $n^{\circ} 49$, um juízo de desproporcionalidade, em que se constatou que a regulação restritiva, nos casos analisados, não seria constitucionalmente justificada, em cotejo com os valores e princípios nela inscritos. Sendo, entretanto, possível a restrição em caso de haver interesse público apto a justificá-la, como por exemplo, "previsão de distância mínima entre dois postos de gasolina". Fica claro que, quaisquer que sejam os valores a contrapor-se à regulamentação municipal, não se justifica que, sob um exame de ponderação, simplesmente por tratar-se de uma regulação de abrangência local, imponha-se uma carga maior ou menor de efetividade das garantias individuais.

55. A atividade de fiscalização em âmbito municipal está bastante associada à ideia de regulação e ao poder de polícia municipal. Assim, sempre que houver um, é possível que se verifique o outro. Em contrapartida, não se deve tomar o poder de polícia como critério apto a verificar competências federativas, já que se trata de prerrogativa transversal do Estado, detida por todos os entes federados. De maneira geral, o Poder de Polícia está contido no art. 174, da CF, e parece induvidoso que os mesmos limites ao exercício do poder de política, bastante encontradiços nos direitos e liberdades 
individuais (e.g. liberdade de expressão, livre iniciativa, propriedade, etc.), são verificados nas atividades de regular ou fiscalizar a economia.

56. Quando se passa em revista o tema do planejamento na Constituição Federal de 1988, constata-se um todo concatenado, na direção da articulação de planos nacionais, regionais e locais. Conforme o art. 21, IX, compete à União elaborar e executar planos nacionais e regionais de ordenação do território e de desenvolvimento econômico-social, enquanto que os Estados poderão, mediante Lei Complementar, instituir regiões metropolitanas, aglomerações urbanas e microrregiões, constituídas por agrupamentos de municípios limítrofes, para integrar a organização, o planejamento e a execução de funções públicas de interesse comum. (art. 25, § $3^{\circ}$, CF). Quanto ao papel dos Municípios, a Constituição foi bastante mais minuciosa, ao prever que compete aos Municípios promover, no que couber, adequado ordenamento territorial, mediante planejamento e controle do uso, do parcelamento e da ocupação do solo urbano (art. 30, VIII, CF). Além disso, dispõe nosso Diploma Maior sobre o modo como o planejamento urbano local deve desenvolver-se, conforme arts. 182 e 183.

57. A Constituição Federal de 1988 foi incisiva na adoção da propriedade com função social, repetindo sua escolha tanto na seção dos direitos e garantias individuais (art. $5^{\circ}$ ) quanto ao tratar dos princípios conformadores da ordem econômica (art. 170). O $\S 2^{\circ}$ do art. 182 dispõe que a propriedade urbana cumpre sua função social quando atende às exigências fundamentais de ordenação da cidade expressas no plano diretor. Há rigorosa diferença no tratamento jurídico dado a bens de consumo e bens de produção, conquanto ambos tenham de cumprir com sua função social. É claro que um bem de produção é distinto de um bem de consumo. Por isso justifica-se que cada tipo de propriedade tenha um tratamento jurídico distinto. A partir de plataformas de compartilhamento de bens, automóveis pessoais e residências, de um uso meramente particular, ganham outra dimensão, tornando-se verdadeiros bens de produção, que visam à reprodução do capital. Nesse passo, torna-se premente a necessidade do planejamento municipal, já que a utilização do solo urbano, considerados seu viário e suas glebas, é constitucionalmente submetido às leis urbanísticas e ao plano diretor do Município, como principais instrumentos de organização urbana. 
58. Por fim, igualmente prevista no artigo 174 do texto constitucional de 1988, a atividade de fomento traduz a função de incentivo à atividade econômica conferida ao Estado brasileiro. Uma vez mais, ressaltamos não haver qualquer distinção, por parte do constituinte originário, sobre qual unidade federativa estatal deverá realizar o fomento. Inclusive, a experiência pátria é rica em exemplos de concessão de incentivos à iniciativa privada, em todos os níveis da Federação. O exemplo mais clássico de incentivo estatal diz respeito à concessão de incentivos fiscais. A aceitação dos incentivos fiscais como modalidade de subvenção acarreta reflexo direto no tratamento do tema pelo Direito Financeiro. Afinal, uma vez considerados como tal, estes incentivos deverão ter seus impactos orçamentários explicitados nas leis orçamentárias, a fim de se evitar escamoteamento de receitas ou "privilégios odiosos".

59. Além disso, a chamada "guerra fiscal" entre municípios é balizada por regras de observância nacional, que importam, por exemplo, em patamares mínimo e máximo das alíquotas do ISS, bem como proibição de exclusão de valores de sua base de cálculo, fora das hipóteses previstas em lei complementar nacional. Nada obstante, há parâmetros e balizas dentro dos quais o Município pode, sim, valer-se dos mecanismos tributários para fomentar atividades econômicas dentro de seu território, desde que, como vimos, esteja de acordo com as regras constitucionais e nacionais de regência.

60. Há ainda, muitas outras formas de fomento como subsídio indireto ou contratações públicas (as quais são percebidas de forma cada vez mais cooperativa e colaborativa). Em resumo, a atividade de fomento do Estado, e aqui mais especificamente pelo Município, deve ater àquela zona de intersecção onde se encontram o interesse público e interesse privado, sempre levando em consideração os valores do direito à cidade e da universalização do acesso a bens e serviços no território do município. 


\section{BIBLIOGRAFIA}

AGUILLAR, Fernando Herren. Direito Econômico: Do Direito Nacional ao Direito Supranacional. $3^{\mathrm{a}}$ ed. São Paulo: Atlas, 2012.

ALEXY, Robert. Teoria dos Direitos Fundamentais. Trad. Vírgilio Afonso da Silva. São Paulo: Malheiros, 2017.

ALMEIDA, Fernanda Dias Menezes de. Competências na Constituição de 1988. $2^{\mathrm{a}}$ ed. São Paulo: Atlas, 2000.

ALMEIDA, Fernando Dias Menezes de. Crítica ao tratamento constitucional do Município como ente da Federação brasileira. Revista de Direito Constitucional e Internacional, v. 17, n. 68., jul.-set., 2009. p. 76-85.

Poder de Polícia - Alguns Aspectos Extraídos de Decisões Recentes do Supremo Tribunal Federal in MEDAUR, Odete; SCHIRATO, Vitor. Poder de Polícia na Atualidade. Belo Horizonte: Editora Fórum, 2014.

ALVES, Alaôr Caffé. A competência municipal e o planejamento metropolitano: Notas sobre a possibilidade jurídica do entrosamento compulsório entre o Estado e os Municípios da Grande São Paulo para o planejamento metropolitano. InBARROSO, L. R.; CLÈVE, C. M. (org). Doutrinas Essenciais: Direito Constitucional, v. 3. São Paulo: RT, 2013.

ARAÚJO, Edmir Netto de. O Município e a proteção do consumidor. Boletim do Centro de Estudos da PGE/SP, São Paulo, v. 14, n.4, 1990. 
ARRETCHE, Marta. A Centralização no Estado Federativo Brasileiro. Tese de Livre de Docência. Faculdade de Filosofia, Letras e Ciências Humanas. Universidade de São Paulo. 2007.

ÁVILA, Humberto. Teoria da Segurança Jurídica. São Paulo: Malheiros, 2016.

. Teoria dos Princípios: da definição à aplicação dos princípios jurídicos. São Paulo: Malheiros, 2014.

AVILA, Marta Marques. A Competência do Município no Direito Constitucional Brasileiro. Tese de Doutorado. Faculdade de Direito da Universidade Federal do Rio Grande do Sul. Porto Alegre, 2013.

BAGNOLI, Vicente. Poder Econômico e Imperialismo: A relação entre Público e Privado in Revista da Faculdade de Direito da Universidade de São Paulo, v. 101, jan./dez. 2006, pp. $587-624$.

BANDEIRA DE MELlO, Celso Antônio. Curso de Direito Administrativo. $26^{\mathrm{a}}$ ed. São Paulo: Malheiros, 2014.

Novos Aspectos da Função Social da Propriedade no Direito Público. Revista de Direito Público, v. 84, n. 39, out/dez. 1987.

BANDEIRA DE MELLO, Oswaldo Aranha. Sociedade e Estado. Revista de Direito Público, n.15, v. 43, jan/mar. de 1971. 
BARACHO, José Alfredo de Oliveira. Teoria geral do federalismo. Belo Horizonte: Fumarc/UFMG, 1982.

. Novos Rumos do Federalismo. Revista de Direito Público, São Paulo: RT, n. 65, v.5, jan/mar de 1986.

O princípio da subsidiariedade. Revista de Direito Administrativo, n. 200, p. 2154, abr./jun. 1995.

O Princípio da Subsidiariedade: Conceito e Evolução. Rio de Janeiro: Editora Forense, 2000.

BARRETO FILHO, Oscar. Limites Constitucionais da Intervenção do Estado na Economia Privada in BARROSO, L. R.; CLÈVE, C. M. (org). Doutrinas Essenciais: Direito Constitucional, v. 6. São Paulo: Revista dos Tribunais, pp. 777-784, 2011.

BARROSO, Luiz Roberto. A ordem econômica constitucional e os limites à atuação estatal no controle de preços.Revista Diálogo Jurídico, Salvador, nº 14, jun./ago. de 2002.

Curso de Direito Constitucional Contemporâneo: os conceitos fundamentais e a construção do novo modelo. Saraiva, São Paulo, 2009.

BASTOS, Celso Ribeiro. O controle judicial da constitucionalidade das leis e atos normativos municipais. São Paulo: Revista de Direito Público, v. 37-38, jan.-jun., 1976.

A constitucionalidade de projetos de lei municipais que visam regulamentar as empresas de estacionamento. In: BARROSO, L. R.; CLÈVE, C. M. (org). Doutrinas Essenciais: Direito Constitucional, v. 3. São Paulo: Revista dos Tribunais, 2011. . Hermenêutica e Interpretação. São Paulo: Celso Ribeiro Bastos Editor, 1999.

BERCOVICI, Gilberto. Dilemas do Estado federal brasileiro. Porto Alegre: Livraria do Advogado, 2004. 
. Direito Econômico do Petróleo e dos Recursos Minerais. São Paulo: Quartier Latin, 2011.

Direito Econômico Aplicado: Estudos e Pareceres. São Paulo: Contracorrente, 2016.

A Constituição de 1988 e a Função Social da Propriedade in BARROSO, L.

R.; CLÈVE, C. M. (org). Doutrinas Essenciais: Direito Constitucional, v. 6. São Paulo: Revista dos Tribunais, 2011.

. Soberania e Constituição: Para uma Crítica do Constitucionalismo. São

Paulo: Quartier Latin, 2013.

BERCOVICI, Gilberto; MASSONETTO, Luís Fernando. Limites da regulação: esboço para uma crítica metodológica do "novo direito público da economia. Revista de Direito Público da Economia, Belo Horizonte, ano 7, n. 25, jan./mar. 2009. Disponível em: http://www.bidforum.com.br/bid/PDI0006.aspx?pdiCntd=56978. Acesso em 18 de junho de 2018.

BREGA, José Fernando Ferreira. Lei Orgânica do Município de São Paulo Anotada: atualizada até a Emenda $n^{o}$ 28/2006. São Paulo: Páginas e Letras: Associação dos Procuradores do Município de São Paulo, 2006.

BOBBIO, Norberto. Da Estrutura à Função. Barueri: Manole, 2007. . Teoria do Ordenamento Jurídico. São Paulo: Edipro, 2014.

BOBBIO, Norberto; MATTEUCCI, Nicola; PASQUINO, Gianfranco. Dicionário de Ciências Políticas. Brasília: Editora UNB, 2010.

BONAVIDES, Paulo, Curso de Direito Constitucional, 12ª ed, São Paulo, Malheiros, 2002. 
BUCCI, Maria Paula Dallari. Direito e Políticas Públicas. São Paulo: Saraiva, 2006.

CAGGIANO, Monica Herman Salem. Federalismo Incompleto: Descentralização e Indefinição de Competências. In Revista Direito Mackenzie, n. 2, ano 1, 2000. p. 31 -44. . Direito Econômico Constitucional (coord.). Barueri: Minha Editora, 2007. O Município no marco da federação: uma radiografia da questão atinente à confiança legítima. In MARTINS, Ives Gandra da Silva; PASIN, João Bosco Coelho (org.). Direito administrativo municipal - temas fundamentais $e$ atuais. São Paulo: Editora Magister, 2007.

CAGGIANO, Monica Herman Salem (coord.); RANIERI, Nina (coord.). As novas fronteiras do federalismo. São Paulo: Imprensa Oficial do Estado de São Paulo, 2008. , Federalismo Incompleto: Descentralização e Indefinição de Competências. In Revista Direito Mackenzie, n. 2, ano 1, 2000. p. 31 -44. . Direito Econômico Constitucional (coord.). Barueri: Minha Editora, 2007. O Município no marco da federação: uma radiografia da questão atinente à confiança legítima. In MARTINS, Ives Gandra da Silva; PASIN, João Bosco Coelho (org.). Direito administrativo municipal - temas fundamentais e atuais. São Paulo: Editora Magister, 2007.

CAGGIANO, Álvaro T.; VERDEROSI, Lucas Reis. Eficiência Administrativa: 'Bússola' Apontada Para Racionalização Do Controle Da Administração Pública in Estudos de Direito Constitucional - Homenagem à Professora Monica Herman Salem Caggiano. Belo Horizonte: Arraes Editores, 2017, pp. 28-39.

CANOTILHO, José Joaquim Gomes. Direito Constitucional e Teoria da Constituição. $7^{\mathrm{a}}$ ed. Lisboa: Almedina, 2002. 
CARVALHO, José Murilo de (org.). Visconde do Uruguai. Coleção Formadores do Brasil. São Paulo: Ed. 34, 2002.

CARVALHO, Vínicius Marques de; MATTIUZZO, Marcela. Confiança, Reputação e Redes: Uma nova lógica econômica? in ZANETTA, R.; PAULA, R.; KIRA, B. (org.) Economias do Compartilhamento e o Direito. Curitiba: Juruá, 2017.

CASTRO, José Nilo. Direito Municipal Positivo. Belo Horizonte: Del Rey, 2010.

CLARK, Giovani. A Intervenção do Município no Domínio Econômico. Revista da Faculdade de Direito da Universidade de Minas Gerais, 2001, pp. 191-207.

COMPARATO, Fábio Konder. O indispensável Direito Econômico, Revista dos Tribunais, n³53, São Paulo, RT, março de 1965, pp. 14-26.

Função Social da Propriedade dos Bens de Produção. São Paulo, Revista de Direito Mercantil, n. 63, 1986.

COSTÓDIO FILHO, Ubirajara. As Competências do Município na Constituição de 1988. São Paulo: Celso Bastos Editor, 2000.

COUTINHO, Diogo R (org). Direito Econômico Atual. São Paulo: Método, 2015.

CRETELLA JR., José. Direito Municipal. São Paulo: Leud, 1975. 
DALLARI, Adilson de Abreu. Organização Municipal. Revista de Direito Público, n $^{\circ} 16$, São Paulo, 1971. p. 298-301. Autonomia municipal na Constituição Federal de 1988. Cadernos de Direito Municipal. São Paulo, v. 97, jan./mar. 1991.p. 231-238. Planejamento Municipal in MARTINS, Ives; GODOY, Mayr. Tratado de Direito Municipal. São Paulo: Quartier Latin, 2012.

DALLARI, Dalmo de Abreu. Normas gerais sobre saúde no Estado federal brasileiro: cabimento e limitações. Revista Latino-Americana de Estudos Constitucionais, $\mathrm{n}^{\mathrm{o}} \mathrm{I}$, jan./jun,. Belo Horizonte: Editora Del Rey, 2003.p. 121-135. Auto-organização do Município. Revista de Direito Público, no 37-38, São Paulo, 1976. p. 297-305. O Estado Federal. São Paulo: Saraiva, 2019.

DI PIETRO, Maria Sylvia. Direito Administrativo. $28^{\mathrm{a}}$ ed. São Paulo: Forense, 2015.

DUGUIT, Léon. Traité de Droit Constitucionnel, $3^{\mathrm{a}}$ ed., tome I, 1927.

ELUSTIZA, Angel Sustaeta. Propriedad y Urbanismo: Lo Urbanístico como limite del derecho de propriedad. Madrid: Editorial Montecorvo S.A. 1978.

FERNÁNDEZ, José Manuel Pérez. Urbanismo Comercial y Liberdad de Empresa. Madrid: Marcial Pons - Ediciones Jurídicas y Sociales, 1998.

FERRARI, Regina de Macedo Nery. A inconstitucionalidade da lei municipal. Curitiba: Juruá, 1991. 
. Elementos de Direito Municipal. São Paulo: Revista dos Tribunais, 1993.

Controle de Constitucionalidade das Leis Municipais. São Paulo: Revista dos

Tribunais, 2003.

FERREIRA FILHO, Manoel Gonçalves. O Estado Federal Brasileiro. Revista da Faculdade de Direito da USP, São Paulo, 1982. p. 131-140.

. Curso de Direito Constitucional. 36 ed. São Paulo: Saraiva, 1999.

. O Poder Constituinte. $5^{\text {a }}$ ed. São Paulo: Saraiva, 2005.

FERRAZ, Luciano. Município e Federalismo in NASCIMENTO, C.; DI PIETRO, M. S. Z.;

MENDES, G. Tratado de Direito Municipal. Belo Horizonte: Fórum, 2018.

FERRAZ JR., Tércio Sampaio. Introdução ao Estudo do Direito: Técnica, Decisão, Dominação. São Paulo: Atlas, 2007.

FERRAZ JR., Tércio Sampaio; NUSDEO, Fabio \& SALOMÃO FILHO, Calixto (org.) Poder Econômico: direito, pobreza, violência, corrupção. Barueri: Manole, 2009.

FORGIONI, Paula Andrea. Os Fundamentos do Antitruste. $8^{\mathrm{a}}$ ed. São Paulo: Revista dos Tribunais, 2015.

FRANCO SOBRINHO, Manoel de Oliveira. A intervenção do Estado na Ordem Econômica in Revista de Direito Público, v. 11, São Paulo, 1970.

GABARDO, Emerson; REZENDE, Maurício C. M. O Conceito de Interesse Público no Direito Administrativo Brasileiro. Revista Brasileira de Estudos Políticos, Belo Horizonte, n. 115, pp. 267-318, jul./dez. 2017. 
GAMA, Guilherme Calmon Nogueira. A Autonomia do Município Brasileiro. Revista Jurídica, Instituição Toledo de Ensino, Bauru, 2006.

GODOY, Mayr. A Lei Municipal. São Paulo: José Buschatsky Editor, 1974.

GONZALES, Douglas Camarinha. Competência legislativa dos entes federados; conflitos e interpretação constitucional. Dissertação de mestrado - Faculdade de Direito da Universidade de São Paulo. 2011.

GRAU, Eros Roberto. Intervenção estadual em município. Revista de Direito Público, v. 21, n. 86, p. 189-198, abr./jun. 1988.

Direito Posto e Pressuposto. $8^{\text {a }}$ ed. São Paulo, Malheiros, 2014. .A Ordem Econômica na Constituição de 1988. 21 a ed. São Paulo, Malheiros, 2019. . Elementos de Direito Econômico. São Paulo: Malheiros, 1981. Intervenção do Estado na Economia in BARROSO, L. R.; CLÉVE, C. Doutrinas Essenciais - Direito Constitucional, v. 6, 2011, pp. 369-401.

HACHEM, Daniel W. A Dupla Noção Jurídica de Interesse Público no Direito Administrativo. Revista de Direito Administrativo e Constitucional, Belo Horizonte, Fórum, ano 11, n. 44, pp. 59-110, 2011.

HAMILTON, Alexander; JAY, John; MADISON, James. The Federalist. Indianopolis: Liberty Fund, 2001. 
HARDIN, Garrett. The Tragedy of the Communs. Science, vol. 162, No. 3859.

HIRSCHMAN, Albert. Os interesses e as paixões: Argumentos Políticos a favor do Capitalismo antes do seu triunfo. Rio de Janeiro: Paz e Terra, 1979.

HOBBES, Thomas. Leviatã. São Paulo: Martins Fontes, 2008.

HOFFMAN, Lisa. Urban Modeling and Contemporary Technologies of City-Building in China: The Production of Regimes of Green Urbanisms. in Worlding Cities: Asian Experiments and the Art of Being Global, 2011.

HORBACH, Carlos Batisde. Forma de Estado: Federalismo e Repartição de Competências in Revista Brasileira de Políticas Públicas, v. 3, n.2. Jul-Dez, 2012. p. 2 - 14.

HORTA, Raul Machado. Posição dos Municípios no Direito Constitucional Federal Brasileiro. Revista de Informação Legislativa. Brasília, ano 19, n.75, jul./set. 1982, pp. 107122.

.Tendências do federalismo brasileiro. In: BARROSO, L. R.; CLÈVE, C. M. (org). Doutrinas Essenciais: Direito Constitucional, v. 3. São Paulo: RT, 2011. pp. 211-220. . Tendências atuais do federalismo brasileiro. Revista da Academia Brasileira de Letras Jurídicas. Rio de Janeiro, v. 10, n. 9, jan./jul. de 1996, pp. 209-225.

HUAT, Chua Beng. Singapore as a Model in Worlding Cities: Asian Experiments and the Art of Being Global, 2011. 
IBGE. Instituto Brasileiro de Geografia e Estatística. Pesquisa Nacional por Amostra de Domicílios Contínua, 2018.

JUSTEN FILHO, Marçal. A Organização Político-Administrativa do Município in MARTINS, Ives; GODOY, Mayr. Tratado de Direito Municipal. São Paulo: Quartier Latin, 2012.

Direito Administrativo do Espetáculo in ARAGÃO, A.; MARQUES NETO, F. A. (org.) Direito Administrativo e seus novos paradigmas. Belo Horizonte: Fórum, 2009.

KARNAL, Leandro. História dos Estados Unidos. São Paulo: Editora Contexto, 2018.

KANT, Immanuel. A Paz Perpétua. Trad. Marco Zingano. Porto Alegre: L\&PM, 2008.

KATZ, Ellis; TARR, G. Alan. Federalism and Rights. Boston: Rowman \& Littlefield Publishers, 1996.

LEAL, Victor Nunes. Coronelismo, enxada e voto - O município e o regime representativo no Brasil. $4^{\mathrm{a}}$ ed. São Paulo: Companhia das Letras, 2012.

LEMBO, Cláudio. A Pessoa e Seus Direitos. São Paulo: Manole, 2007. Visões do Cotidiano (org.) São Paulo: Manole, 2012.

LENZA, Pedro. Direito Constitucional Esquematizado. São Paulo: Saraiva, 2018. 
LEWANDOWSKI, Enrique Ricardo. Pressupostos materiais e formais da intervenção federal no Brasil. São Paulo: Revista dos Tribunais, 1992.

. Globalização, regionalização e soberania. São Paulo: Juarez de Oliveira, 2004.

LOPES, José Reinaldo Lima. O Direito na História: Lições Introdutórias. $6^{\text {a }}$ Ed. São Paulo: Atlas, 2019.

MACHADO, Hugo de Brito. Curso de Direito Tributário. São Paulo: Malheiros, 2013.

MALUF, Adriana C. R. F. Dabus. Limitações urbanas ao direito de propriedade. São Paulo: Atlas, 2010.

MARQUES NETO, Floriano de Azevedo. Fomento in Tratado de Direito Administrativo. DI PIETRO, Maria Sylvia (org.). v. IV, São Paulo: Revista dos Tribunais, 2014. . Regulação Estatal e Interesses Públicos. São Paulo: Malheiros, 2002. Os Serviços de Interesse Econômico Geral e as Recentes Transformações dos Serviços Públicos. Belo Horizonte: Fórum Administrativo, n. 154, p. 9-22, 2013.

MARTINS, Ives Gandra; PASIN, João Bosco C. Direito Administrativo Municipal: Temas Fundamentais e Atuais. Porto Alegre: Magister Editora, 2007.

MASSONETTO, Luís Fernando. Pontos Cegos da Regulação Urbanística: Notas sobre uma articulação programática entre o Direito Econômico e o Direito Urbanístico. Revista Fórum de Direito Econômico e Financeiro. Belo Horizonte, ano 4, n. 6, set./fev., 2015. pp. 141-154. 
MATTOS, Paulo Todescan Lessa. O novo Estado regulador no Brasil: eficiência e legitimidade. São Paulo: Fapesp/Singular, 2006.

MEDAUAR, Odete. Direito Administrativo Moderno. $17^{\mathrm{a}}$ ed. São Paulo: Revista dos Tribunais, 2013.

. Direito Administrativo em Evolução. $3^{\mathrm{a}}$ ed. São Paulo: Gazeta Jurídica, 2017.

MEDAUAR, Odete; SCHIRATO, Victor. (coord.) Poder de Polícia - Origem, evolução, crítica à noção, caracterização in Poder de Polícia na Atualidade. Belo Horizonte: Editora Fórum, 2014.

MENDES, Gilmar Ferreira; BRANCO, Paulo; COELHO, Inocência. Curso de Direito Constitucional. São Paulo: Saraiva, 2009.

MEIRELLES, Hely Lopes. Direito Administrativo Brasileiro. São Paulo, Malheiros, 2001. Direito Municipal Brasileiro. São Paulo: Malheiros, 40ª ed. 2013.

MIRANDA, Jorge. Formas e Sistemas de Governo. Rio de Janeiro: Editora Forense, 2007.

MOHN, Paulo. A Repartição de Competências na Constituição de 1988. Brasília: Revista a. 47 , n. 187 , jul/set. 2010.

MONTESQUIEU, Baron de. Do Espírito das Leis. Trad. Roberto Leal Ferreira. São Paulo: Martin Claret, 2014. 
MORAES, Alexandre de. Competência, trânsito e transporte intermunicipal perante a constituição federal. Revista do Instituto dos Advogados de São Paulo, v. 3, 2012. p. 805811.

MOREIRA, Vital. A ordem jurídica do capitalismo. 4. ed. Lisboa: ed. Caminho, 1987. Economia e Constituição: para o conceito de constituição económica. Coimbra: Faculdade de Direito de Coimbra, 1974.

MOREIRA NETO, Diogo Figueiredo. Organização dos Municípios in MARTINS, Ives; GODOY, Mayr. Tratado de Direito Municipal. São Paulo: Quartier Latin, 2012.

NOGUEIRA, Ataliba. Teoria do Município. Revista de Direito Público. São Paulo: Editora Revista dos Tribunais, v. 6, out./dez., 1968. pp. 7-21.

OCTAVIANI; Alessandro; NOHARA, Irene P. Estatais. São Paulo: Revista dos Tribunais, 2019.

OLIVEIRA, Régis F. de. Curso de Direito Financeiro. São Paulo: Revista dos Tribunais, 2010.

PELLEGRINI, Ana; ANDRADE, Gabriela R. de. Mobilidade Urbana e Compartilhamento de Veículos ZANETTA, R.; PAULA, R.; KIRA, B. (org.) Economias do Compartilhamento e o Direito. Curitiba: Juruá, 2017.

PEREZ, Marcos; SOUZA, Rodrigo Pagani de. Controle na Administração Pública. Belo Horizonte: Fórum, 2017. 
PINTO, Victor Carvalho. Direito Urbanístico: Plano Diretor e Direito de Propriedade. $4^{\mathrm{a}}$ Ed. São Paulo: Revista dos Tribunais, 2014.

PIRES, Maria Coeli Simões. A ressemantização da autonomia municipal em face dos desafios contemporâneos. Revista de Informação Legislativa. Brasília, v. 38, nº 149, p. 229242, jan./mar. 2001.

. A autonomia municipal no Estado brasileiro. Revista de Informação Legislativa. Brasília a. 36 n. 142 abr./jun. 1999. P. 143-165.

POLANYI, Karl. A Falácia Economicista in A Subsistência do Homem e Ensaios Correlatos. São Paulo: Contraponto, 2012. . A Grande Transformação: As origens de nossa época. Rio de Janeiro: Elsevier, 2010.

POSNER, Richard. The Constitution as an Economic Document. Chicago: University of Chicago Law School, 1987.

RANGEON, François. L'idéologie de L'intérêt Général. Paris: Economica, 1986.

RANIERI, Nina B. Stocco. Sobre o Federalismo e o Estado Federal. Revista dos Tribunais, Cadernos de Direito Constitucional e Ciência Política, São Paulo, n. 9, 1994. p. 87-98.

RAJAN, Raghuran. The Third Pilar - How Markets and the State Leave Communities Behind. New York: Penguin Press, 2019. 
REALE, Miguel. Competências Constitucionais - Legislação sobre Urbanismo in BARROSO, L. R.; CLÈVE, C. M. (org). Doutrinas Essenciais: Direito Constitucional, v. 3. São Paulo: Revista dos Tribunais, 2011. . Teoria do Direito e do Estado. São Paulo: Martins Fontes, 1970.

REICH, Norbert. Intervenção do Estado na Economia in BARROSO, L. R.; CLÈVE, C. M. (org). Doutrinas Essenciais: Direito Constitucional, v. 6. São Paulo: Revista dos Tribunais, 2011.

RESENDE, Guilherme Mendes. Efeitos Concorrenciais da Economia de Compartilhamento no Brasil: A entrada do Uber afetou o mercado de aplicativos de taxi entre 2014 e 2016 ?. Documento de Trabalho $\mathrm{n}^{\circ}$ 001/2018. Brasília: CADE, 2018. Disponível em http://www.cade.gov.br/acesso-a-informacao/publicacoes-institucionais/dee-publicacoesanexos/documento-de-trabalho-001-2018-uber.pdf. Acesso em 08 de outubro de 2019.

ROMER, Paul. Success and the City: How Charter Cities Could Transform the Development World. Macdonald-Laurier Institute Publication. April, 2012. Technologies, Rules and Progress: The Case for Charter Cities. Center for Global Development, March, 2010.

ROUSSEAU, Jean Jacques. Do Contrato Social. São Paulo: Penguim Companhia, 2011.

SALGADO, Rodrigo Oliveira. 2017. Regulação Econômica do Espaço Urbano e Apropriação do Excedente. Tese de Doutorado. Faculdade de Direito da Universidade de São Paulo, 2017. 
SAlOMÃO FILHO, Calixto. Regulação da Atividade Econômica: Princípios e Fundamentos Jurídicos. $2^{\text {a }}$ ed. São Paulo: Malheiros, 2007.

SANDRONI, Paulo. O Cepac (Certificado de Potencial Adicional de Construção) como Instrumento de Captação de Mais Valias Urbanas e Financiamento de Grandes Projetos. São Paulo, 2014.

SARMENTO, Daniel. Interesses Públicos versus Interesses Privados: Desconstruindo o Princípio da Supremacia do Interesse Público. Rio de Janeiro: Lumen Juris, 2017.

SARMENTO, Daniel; SOUZA NETO, Cláudio. Direito Constitucional: teoria, história e métodos de trabalho. Belo Horizonte: Fórum, 2012.

SCHIRATO, Renata Nadalin Meireles. Interação Público-Privada no Ambiente Urbano: Uma análise dos Instrumentos Jurídicos. Dissertação de Mestrado - Universidade de São Paulo. 2014.

SCHIRATO, Renata; BREGA, José. Função Social da Propriedade Urbana $e$ Condicionamento da Propriedade in Direito Urbanístico: Estudos Fundamentais. Belo Horizonte: Fórum, 2019.

SCHOUERI, Luís Eduardo. Normas Tributárias Indutoras e Intervenção Econômica. São Paulo: Editora Forense, 2005.

SCHWAB, Klaus. The Fourth Industrial Revolution. World Economic Forum. Geneva: 2016. 
SCHWARCZ, Lilia M; STARLING, Heloisa M. Brasil: Uma Biografia. São Paulo: Companhia das Letras, 2018.

SHATKIN, Gavin. Planing Privatopolis: Representation and Contestation in the Development of Urban Integrated Mega-Projects in Model in Worlding Cities: Asian Experiments and the Art of Being Global. 2011.

SILVA, José Afonso da. Curso de Direito Constitucional Positivo. São Paulo, Malheiros, 2016. Direito Urbanístico Brasileiro. $6^{\mathrm{a}}$ ed. São Paulo, Malheiros, 2010.

SILVA, Vírgilio Afonso da. Interpretação Constitucional. São Paulo: Malheiros, 2010.

SOARES, Antonio Carlos Otoni. A Instituição Municipal no Brasil. São Paulo: Ed. Revista dos Tribunais, 1986.

SOUZA, Washington Peluso Albino de. Primeiras linhas de direito econômico. $5^{\mathrm{a}}$ ed. 2003. , O Estatuto da Cidade e o Planejamento. Revista do Tribunal Regional Federal da $1^{\text {a }}$ Região, Brasília v.17, n.9, pp. 34-47, set/2005.

SOUZA, Horácio Augusto Mendes de. Direito Municipal Contemporâneo: Novas tendências. Belo Horizonte: Fórum, 2008.

SPINOZA, B. Ética. Trad. Tomaz Tadeu. São Paulo: Autêntica, 2013. 
SUNDFELD, Carlos Ari. Direito Administrativo Ordenador. São Paulo: Malheiros, 2002.

TAVOLARI, Bianca. Airbnb e os Impasses Regulatórios para o Compartilhamento de Moradia: Notas para uma Agenda de Pesquisa em Direito in ZANETTA, R.; PAULA, Pedro; KIRA, Beatriz. (Org.) Economias do Compartilhamento e o Direito. Curitiba: Juruá, 2017.

TEMER, Michel. Elementos de Direito Constitucional. São Paulo: Saraiva, 1989.

TEIXEIRA, J. H. Meirelles. A Competência Municipal na Regulação dos Serviços Públicos Concedidos. São Paulo: Departamento Jurídico da Prefeitura do Município de São Paulo, 1948.

TAVARES, André Ramos Tavares. Curso de Direito Constitucional. 10ªed. São Paulo: Saraiva. 2017.

. Direito Constitucional Econômico. $3^{\mathrm{a}}$ ed., vol. 1. São Paulo, Método, 2011.

. A Intervenção do Estado no Domínio Econômico. In: José Eduardo Martins

CARDOZO; João Eduardo Lopez QUEIROZ; Márcia Walquiria Batista dos SANTOS. (Org.). Direito Administrativo Econômico. 1ed. São Paulo: Editora Atlas, 2011, v. 1, p. 225256.

. Princípios Constitucionais in: MARTINS, Ives Gandra M. da; MENDES, Gilmar F.; NASCIMENTO, Carlos V. (Coord.) Tratado de Direito Constitucional, v. 1, $2^{\mathrm{a}}$ Ed. São Paulo: Saraiva, 2012.

As Duas Cartas: Da terra ao bosque in Revista Brasileira de Estudos Constitucionais, São Paulo, v. 33. 
URUGUAI, Visconde do. Ensaio sobre Direito Administrativo. Apres. Nelson Jobim. Brasília: Ministério da Justiça, 1997.

VALDIVIA, Diego Zegara. Del Servicio Público a los Servicios de Interés General: La evolución del servicio público en el sistema jurídico. Lima: Círculo de Derecho Administrativo, 2012.

VENÂNCIO FILHO, Alberto, A Intervenção do Estado no Domínio Econômico, $2^{\mathrm{a}}$ ed, Rio de Janeiro, Renovar, 1998.

VERDEROSI, Lucas Reis. O Tarantinesco The Hangman e o Tal Comportamento Institucional. Artigo publicado em 03 de setembro de 2018. Disponível em: https://www.conjur.com.br/2018-set-03/lucas-verderosi-the-hangman-tal-comportamentoinstitucional?utm_source=dlvr.it\&utm_medium=facebook.

VIDIGAL, Geraldo Camargo. Teoria Geral do Direito Econômico. São Paulo: RT, 1977.

WEBER, Max. A Ética Protestante e o Espírito do Capitalismo. Trad. José Marcos Mariani de Macedo. São Paulo: Companhia das Letras, 2014.

ZAGO, Mariana Augusta. Federalismo no Brasil e na Alemanha. Tese de Doutorado. Faculdade de Direito. Universidade de São Paulo, 2016.

ZANETTA, R.; PAULA, Pedro; KIRA, Beatriz. Inovações Regulatórias No Transporte Individual: O Que Há De Novo Nas Megacidades Após O Uber? in ZANETTA, R.; PAULA, Pedro; KIRA, Beatriz. (Org.) Economias do Compartilhamento e o Direito. Curitiba: Juruá, 2017. 